\title{
Artifact Assemblages from San Augustine County, Texas, Sites Recorded in 1939-1940 by Gus E. Arnold
}

Timothy K. Perttula

Heritage Research Center, Stephen F. Austin State University

Follow this and additional works at: https://scholarworks.sfasu.edu/ita

Part of the American Material Culture Commons, Archaeological Anthropology Commons, Environmental Studies Commons, Other American Studies Commons, Other Arts and Humanities Commons, Other History of Art, Architecture, and Archaeology Commons, and the United States History Commons

Tell us how this article helped you.

This Article is brought to you for free and open access by the Center for Regional Heritage Research at SFA ScholarWorks. It has been accepted for inclusion in Index of Texas Archaeology: Open Access Gray Literature from the Lone Star State by an authorized editor of SFA ScholarWorks. For more information, please contact cdsscholarworks@sfasu.edu. 


\section{Artifact Assemblages from San Augustine County, Texas, Sites Recorded in}

1939-1940 by Gus E. Arnold

\section{Creative Commons License}

\section{(c) (1) (8)}

This work is licensed under a Creative Commons Attribution-NonCommercial 4.0 International License 


\title{
Artifact Assemblages from San Augustine County, Texas, Sites Recorded in 1939-1940 by Gus E. Arnold
}

\author{
Timothy K. Perttula
}

\section{Introduction and Site Settings}

During the 1939-1940 WPA-sponsored archaeological survey of East Texas, Gus E. Arnold was particularly active in identifying and recording sites in San Augustine County, in the East Texas Pineywoods (see Perttula 2015a, 2017a), as well as sites along Patroon, Palo Gaucho, and Housen bayous in neighboring Sabine County (Perttula 2015b, 2017b), and sites in the Angelina River basin in Angelina County (Perttula 2016c). During his archaeological survey efforts, he collected substantial assemblages of ceramic and lithic artifact assemblages (curated by the Texas Archeological Research Laboratory at The University of Texas at Austin), primarily due to the fact that the surface of sites were well-exposed because of plowing, and he was encouraged to collect robust artifact assemblages by A. T. Jackson, the WPA survey director at The University of Texas at Austin. This article concerns the analysis of the recovered artifact assemblages from 14 different WPA sites in various parts of San Augustine County (Figure 1).

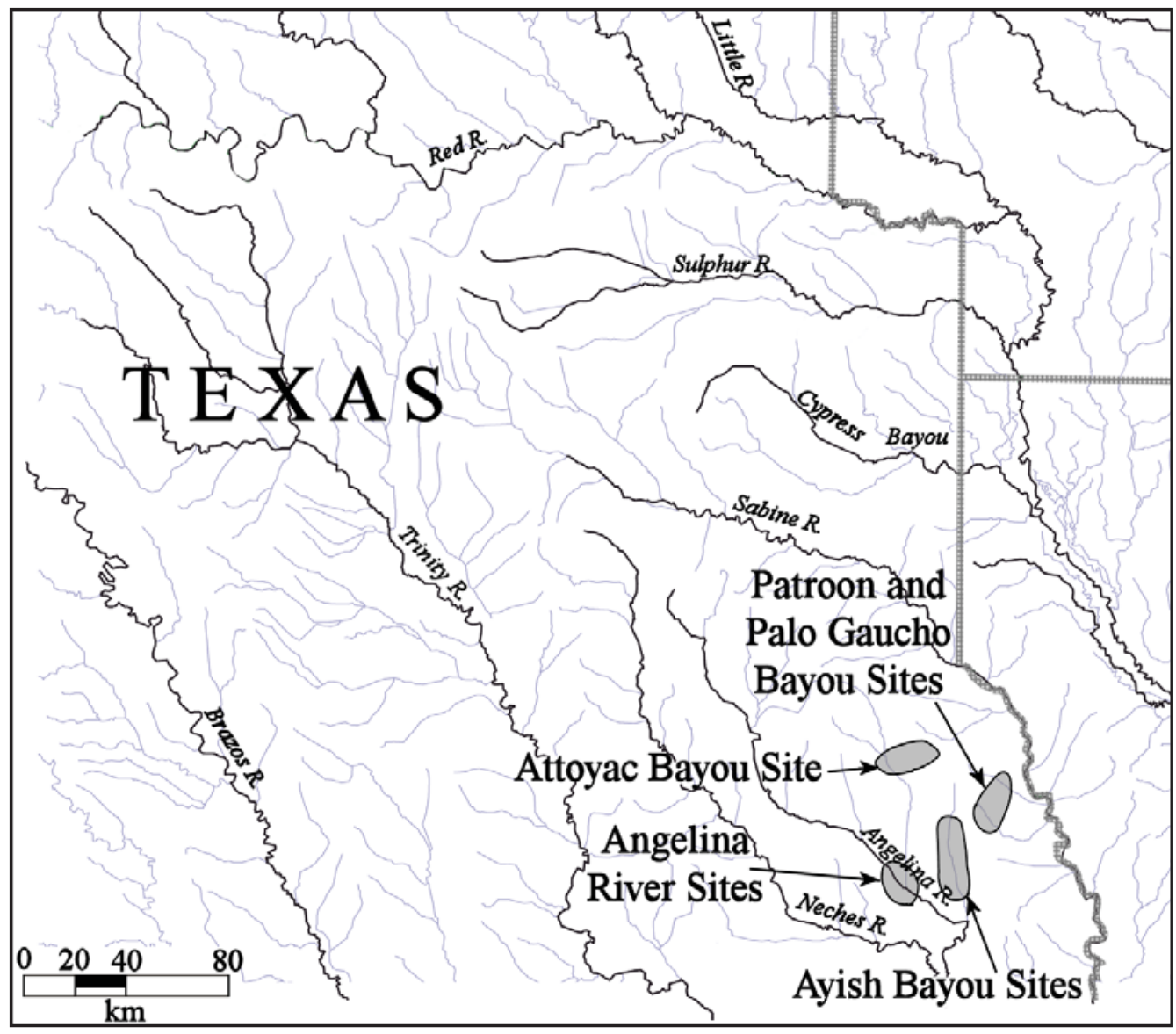

Figure 1. General location of sites and stream basins discussed in this article. 
The 14 archaeological sites are situated in several different stream basins, on a variety of landforms (i.e., floodplain rise, alluvial terrace, and upland ridge), including the Attoyac Bayou basin (41SA1 on Attoyac Bayou; 41SA5, at junction of Little and Big Arenosa Creek; 41SA24 on Price Creek; 41SA9, 41SA15, and 41SA16, Arenosa Creek), Patroon Bayou in the Sabine River basin (41SA11 and 41SA32), Palo Gaucho Bayou in the Sabine River basin (41SA108), Ayish Bayou (41SA77, 41SA80, 41SA95, and 41SA96) in the Angelina River basin; and Hog-Harvey creeks (41SA85) in the Angelina River basin.

According to Arnold, these sites ranged from 1-6 acres in size, based on the surface distribution of artifacts as well as the extent of the landforms. In the case of the Hanks site (41SA80), midden deposits marked by mussel shells and animal bones were preserved there. The landowner had also previously collected two ceramic pipes, a celt, and a $33 \mathrm{~cm}$ long notched chert biface from the site. Burned and unburned animal bones were also noted on the surface of the Frost Johnson Lumber Co. site (41SA5); and burials associated with ceramic vessels and other material remains were noted when the site was first put into cultivation. Whole ceramic vessels from ancestral Caddo burial features had been reported to have eroded out of the Allan Howill (41SA24) and J. McGilberry (41SA85) sites. The Allan Howill site also had mussel shells and fragments of animal bone visible on the surface, and an area with ancestral Caddo burials (at least three with skeletal remains) was reported on the edge of an upland bluff there. Arnold also excavated several test pits of unknown size at the D. C. Hines site (41SA95), where he encountered archaeological deposits between ca. 60-76 cm bs. Arnold also noted "exceptionally large quantities of petrified wood, chert and flint flakes and chips cover the surface" of the D. C. Hines site.

\section{Chipped and Ground Stone Tools}

Chipped stone tools $(n=95)$ and one sandstone ground stone tool are present in the various San Augustine County sites, and they represent episodic use of the region from as early as the Late Paleoindian period (ca. 10,500-9800 years B.P.) to post-A.D. 1200 to A.D. 1400+ times (in the case of the numerous Perdiz arrow points). The chipped stone tools are made from a variety of lithic raw materials (Table 1), including local cherts, quartzite, and petrified wood as well as non-local cherts likely originating in Central Texas.

Table 1. Chipped stone tools and raw material use in the San Augustine County WPA sites.

\begin{tabular}{lllllll}
\hline Tool types & local chert & QTZ & PW & $\begin{array}{l}\text { non-local } \\
\text { chert }\end{array}$ & SS & N \\
\hline $\begin{array}{l}\text { Late Paleoindian } \\
\text { Late Archaic DP }\end{array}$ & - & - & - & 2 & - & 2 \\
Woodland DP & 5 & - & 6 & 4 & - & 12 \\
UID DP & 2 & 2 & 4 & 3 & - & 14 \\
pre-A.D. 1200 AP & 12 & - & 2 & - & - & 12 \\
$\begin{array}{l}\text { Post-A.D. 1200 AP } \\
\text { UID AP and }\end{array}$ & 14 & - & - & - & - & 19 \\
AP preforms & 6 & 1 & - & 2 & - & 9 \\
Flake tools/drill & - & & & & & \\
bifaces & 6 & - & 1 & 2 & - & 20 \\
mano & - & - & - & - & 1 & 1 \\
\hline Totals & 47 & 7 & 25 & 16 & 1 & 96 \\
\hline
\end{tabular}

$\mathrm{DP}=$ dart point; $\mathrm{AP}=$ arrow point; $\mathrm{QTZ}=$ quartzite; $\mathrm{PW}=$ petrified wood; $\mathrm{SS}=$ sandstone; local chert: brown, red, reddish-gray 
Local cherts were used in 49 percent of the tools, particularly in the manufacture of both pre- A.D. 1200 (100 percent) and post-A.D. 1200 arrow points (73.7 percent) found on the sites (see Table 1). Petrified wood was also an important source of raw material for tool manufacture, most notably in discarded and broken bifaces (55 percent) and in the manufacture of Late Archaic and Woodland period dart points. Quartzite was used for the manufacture of only 7.3 percent of the tools in these assemblages, but 28.6 percent of the Woodland period dart points were made from this material, as were 10.5 percent of the post-A.D. 1200 arrow points. By contrast, non-local cherts account for 100 percent of the Late Paleoindian dart periods, 33 percent of the Late Archaic dart points, 21 percent of the Woodland dart points, 10.5 percent of the post-A.D. 1200 arrow points, 67 percent of the flake tools/drill, and only 5 percent of the biface fragments (see Table 1). The downward temporal trend in the use of non-local chert raw materials likely represents a decreasing mobility through time after the Late Paleoindian period (after ca. 9800 years B.P.), as East Texas groups thereafter had less access to non-local raw materials (either by direct procurement or through exchange/trade), and came to rely on local cherts, petrified wood, and quartzite available in nearby stream gravels.

There are two Late Paleoindian dart points in the 41SA108 artifact assemblage. They include a San Patrice point made from a very dark brown chert and a Dalton point made from a dark grayish-brown chert likely from the Edwards Formation in Central Texas; both raw materials are clearly not local to East Texas. The Dalton point was broken by a blade impact fracture.

Presumed Late Archaic dart points include a narrow straight-stemmed dart point (brown chert) from the E. D. Kinon Place III Site (41SA15), one Trinity dart point from 41SA1 and another from 41SA24, a Yarbrough dart point from 41SA80, single Morrill points from 41SA95 and 41SA108, a Delhi point from 41SA95, a cf. Edgewood point from 41SA95, as well as straight-stemmed (n=2) and expanding stemcorner-notched $(n=1)$ forms. An unidentified straight stemmed dart point is also in the collections from the Sam Williams site (41SA77).

Among the Woodland period dart points are Gary points $(n=7)$ from the E. D. Kinon Place III site $(n=1), 41$ SA96 $(n=1)$, and 41SA108 $(n=5)$, as well as Kent points from 41SA1 $(n=1)$ and 41SA108 $(n=3)$, as well as single Godley points from 41SA95, 41SA96, and 41SA108.

The pre-A.D. 1200 arrow points in the collections include two Alba points from the Hamp Walldan site (41SA1), two Alba arrow points from the Forest Johnson Lumber Co. site (41SA5), three Alba points from 41SA9, three more points from 41SA95, and one from 41SA16; and a Catahoula point from 41SA95. The post-A.D. 1200 arrow points in the collections include single Bonham points from 41SA9 and 41SA77, and four Bonham points from 41SA95; Perdiz points from 41SA1 ( $\mathrm{n}=1$ ), the Frost Johnson Lumber Co. site $(n=2)$, the E. D. Kinon Place III site ( $n=3)$, 41SA85 $(n=1), 41 S A 95(n=2), 41$ SA96 $(n=1)$, and 41SA108 $(n=2)$, and there is a Perdiz arrow point preform from the E. D. Kinon Place III site. A distal arrow point fragment was collected from 41SA11, four arrow point preforms from 41SA95, and two arrow point preforms are in the 41SA85 collections.

\section{Woodland Period Sandy Paste Ceramic Vessel Sherds}

Small amounts of sandy paste Goose Creek Plain, var. unspecified and Goose Creek Incised vessel sherds (cf. Aten 1983; Story 1990) are present in the artifact assemblages from the majority of these San Augustine County sites (Table 2). This type of aboriginal pottery was made by East Texas Mossy Grove culture peoples during the Woodland period, from ca. 2500-1100 years B.P. (see Ellis 2013). 
Table 2. Sandy paste ceramic sherds from the San Augustine County, Texas sites.

\begin{tabular}{lllll}
\hline Site & GCP rim & GCP body & GCP base & $\begin{array}{l}\text { Decorated Sandy Paste } \\
\text { (Goose Creek Incised) }\end{array}$ \\
\hline 41SA1 & - & 17 & 1 & - \\
41SA5 & 1 & 4 & - & - \\
41SA11 & - & 5 & 1 & - \\
41SA16 & - & 5 & - & 2 (opposed incised lines; \\
41SA32 & - & 24 & 1 & - \\
41SA77 & - & 3 & - & - \\
41SA80 & - & 10 & 1 & - \\
41SA5 & 1 & 20 & - & 2 (parallel incised lines) \\
41SA6 & - & 14 & 1 & 4 \\
41SA108 & - & 12 & 4 & \\
\hline Totals & 2 & 114 & 9 & \\
\hline
\end{tabular}

$\mathrm{GCP}=$ Goose Creek Plain

Only four of the 129 Goose Creek sherds (3.1 percent) in these collections are from decorated Goose Creek Incised vessels (see Table 2). These vessels have simple geometric decorative elements: parallel incised lines or opposed incised lines.

\section{Ancestral Caddo Ceramic Vessel Sherds in the San Augustine County Sites}

Each of these 14 sites in San Augustine County recorded by Gus E. Arnold have collections of ancestral Caddo ceramic vessel sherds. These sherds are almost exclusively from vessels tempered either with grog or burned bone, and in most cases there are high proportions of decorated sherds in each of the assemblages, with the most common decorative elements being comprised of brushing marks on vessel rim and/or body surfaces or different oriented sets of incised lines on utility ware vessels. The sample sizes of the 14 ceramic assemblages range from 90 to 771 sherds.

\section{Hamp Walldan Site (41SA1)}

About 61 percent of the ceramic sherds from the Hamp Walldan site are from grog-tempered vessels, and the remainder of the sherds are from bone-tempered vessels (Table 3 ). The highest proportion of bone-tempered sherds occur in the fine wares ( 57.6 percent) and utility wares ( 52.2 percent), while only 27.1 percent of the plain ware sherds are bone-tempered.

Table 3. Caddo ceramic wares at the Hamp Walldan site (41SA1).

\begin{tabular}{lccc}
\hline Ware & Grog-tempered & Bone-tempered & N \\
\hline Plain & 269 & 100 & 369 \\
Utility & 128 & 140 & 268 \\
Fine & 14 & 19 & 33 \\
\hline Totals & 411 & 259 & 670 \\
\hline
\end{tabular}


The plain to decorated sherd ratio in the assemblage is 1.23 . About 89 percent of the decorated sherds are from utility wares, in particular sherds with brushed, brushed-incised, brushed-incisedpunctated, and brushed-punctated decorative elements (Table 4); these sherds comprise 54.8 percent of all the decorated sherds in the Hamp Walldan collection. The brushed to plain sherd ratio is 0.45 and the brushed to other wet paste sherd ratios is 1.46 . Brushed rim sherds in the assemblage have horizontal or vertical brushing marks.

Table 4. Decorative methods and elements represented in the utility ware and fine ware ceramics at the Hamp Walldan site (41SA1).

\begin{tabular}{llll}
\hline Ware & Rim & Body & $\mathrm{N}$ \\
\hline
\end{tabular}

\section{Utility Ware}

\section{Brushed}

horizontal brushed

opposed brushed

overlapping brushed

parallel brushed

vertical brushed

$\begin{array}{lll}6 & 1 & 7 \\ - & 3 & 3 \\ - & 2 & 2 \\ - & 139 & 139 \\ 3 & - & 3\end{array}$

\section{Brushed-Incised}

parallel brushed-incised marks and lines

parallel brushed and overlying parallel incised

lines

parallel brushed and overlying straight incised

line

\section{Brushed-Incised-Punctated}

horizontal brushed-incised with fingernail

punctated row through the brushing

straight incised line, adjacent tool punctated

row, above parallel brushing marks

\section{Brushed-Punctated}

horizontal brushed with vertical tool punctated 7

row through the brushing

parallel brushed and opposed linear tool

-
-

punctated row through the brushing

tool punctated row above horizontal brushing

\section{Incised}

cross-hatched incised lines

curvilinear incised line

diagonal incised lines

diagonal opposed incised lines

hatched incised oval el.

horizontal incised lines

horizontal incised line beneath the lip

horizontal and diagonal opposed incised lines 
Table 4. Decorative methods and elements represented in the utility ware and fine ware ceramics at the Hamp Walldan site (41SA1), cont.

\begin{tabular}{|c|c|c|c|}
\hline Ware & $\operatorname{Rim}$ & Body & $\mathrm{N}$ \\
\hline opposed incised lines & - & 2 & 2 \\
\hline parallel incised lines & - & 27 & 27 \\
\hline straight incised line & - & 14 & 14 \\
\hline vertical incised lines & 1 & - & 1 \\
\hline \multicolumn{4}{|l|}{ Incised-Punctated } \\
\hline $\begin{array}{l}\text { circular punctated row and adjacent straight } \\
\text { incised line }\end{array}$ & - & 1 & 1 \\
\hline diagonal incised panels filled with tool punctates & 1 & - & 1 \\
\hline $\begin{array}{l}\text { horizontal incised panels with tool punctated } \\
\text { row }\end{array}$ & - & 1 & 1 \\
\hline $\begin{array}{l}\text { parallel incised line and adjacent tool } \\
\text { punctated zone }\end{array}$ & - & 1 & 1 \\
\hline $\begin{array}{l}\text { straight incised line and adjacent circular } \\
\text { punctated zone }\end{array}$ & - & 1 & 1 \\
\hline $\begin{array}{l}\text { straight incised line and adjacent linear tool } \\
\text { punctated zone }\end{array}$ & - & 1 & 1 \\
\hline $\begin{array}{l}\text { straight incised line and adjacent tool } \\
\text { punctated zone }\end{array}$ & - & 2 & 2 \\
\hline $\begin{array}{l}\text { straight incised line and triangular } \\
\text { impressed punctations }\end{array}$ & - & 1 & 1 \\
\hline \multicolumn{4}{|l|}{ Pinched } \\
\hline parallel pinched ridges & - & 1 & 1 \\
\hline \multicolumn{4}{|l|}{ Punctated } \\
\hline circular punctated rows & 1 & - & 1 \\
\hline crescent-shaped fingernail punctates & - & 1 & 1 \\
\hline fingernail punctated rows & - & 21 & 21 \\
\hline vertical fingernail punctated row & 1 & - & 1 \\
\hline tool punctated rows & - & 8 & 8 \\
\hline \multicolumn{4}{|l|}{ Ridged } \\
\hline parallel ridged & - & 2 & 2 \\
\hline \multicolumn{4}{|l|}{ Fine Ware } \\
\hline \multicolumn{4}{|l|}{ Engraved } \\
\hline cross-hatched engraved bracket el. & - & 1 & 1 \\
\hline cross-hatched engraved zone & - & 1 & 1 \\
\hline closely-spaced curvilinear engraved lines & - & 3 & 3 \\
\hline curvilinear engraved lines & - & 6 & 6 \\
\hline
\end{tabular}


Table 4. Decorative methods and elements represented in the utility ware and fine ware ceramics at the Hamp Walldan site (41SA1), cont.

\begin{tabular}{|c|c|c|c|}
\hline Ware & $\operatorname{Rim}$ & Body & $\mathrm{N}$ \\
\hline $\begin{array}{l}\text { curvilinear engraved lines, one line with } \\
\text { excised tick marks }\end{array}$ & - & 1 & 1 \\
\hline curvilinear hatched zone & - & 3 & 3 \\
\hline diagonal and opposed engraved lines & - & 1 & 1 \\
\hline hatched engraved zone & - & 2 & 2 \\
\hline horizontal engraved lines & 1 & 1 & 2 \\
\hline $\begin{array}{l}\text { horizontal engraved line, open bracket el, and } \\
\text { vertical engraved lines }\end{array}$ & - & 1 & 1 \\
\hline $\begin{array}{l}\text { horizontal-diagonal engraved lines and } \\
\text { diagonal hatched zone }\end{array}$ & - & 1 & 1 \\
\hline horizontal and semi-circle engraved el. & - & 1 & 1 \\
\hline opposed curvilinear engraved lines & - & 2 & 2 \\
\hline $\begin{array}{l}\text { opposed curvilinear engraved lines and diagonal } \\
\text { opposed engraved lines }\end{array}$ & - & 1 & 1 \\
\hline parallel engraved lines & - & 2 & 2 \\
\hline scroll el. and scroll fill zone & 1 & - & 1 \\
\hline slanting scroll el. & 1 & - & 1 \\
\hline \multicolumn{4}{|l|}{ Engraved-Red-Slipped } \\
\hline ext. red-slipped and curvilinear engraved line & - & 1 & 1 \\
\hline \multicolumn{4}{|l|}{ Trailed } \\
\hline parallel trailed lines & - & 1 & 1 \\
\hline straight trailed line & - & 2 & 2 \\
\hline Totals & 28 & 273 & 301 \\
\hline
\end{tabular}

Sherds from vessels with incised decorative elements have simple geometric motifs, including diagonal incised lines $(n=3)$, diagonal opposed incised lines $(n=2)$, horizontal incised lines $(n=4)$, one rim with a single horizontal incised line beneath the lip, and vertical incised lines $(n=1)$ (see Table 4). The incisedpunctated sherds from the site have diagonal and horizontal incised panels filled with tool punctates (Figure 2 ), or are likely from vessels with incised triangle elements filled with circular or tool punctates. One incised-punctated sherd has a row of impressed triangles below a single straight incised line, and this sherd

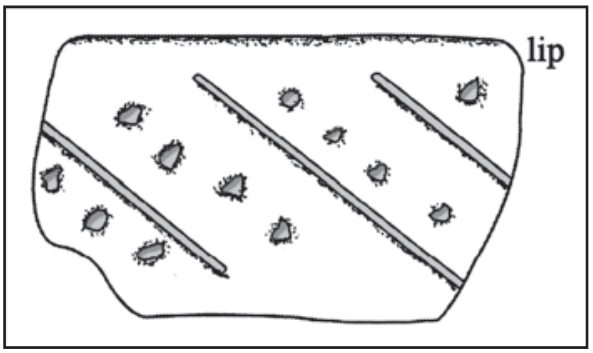

Figure 2. Incised-punctated rim sherd from the Hamp Walldan site (41SA1). may be from a Coles Creek Incised, var. Coles Creek vessel (see Brown 1998:9; Girard 2014:Figure 8o-r), suggesting some use of the Hamp Walldan site between ca. A.D. 9001050, when such decorated vessels are present throughout East Texas and Northwest Louisiana Early Caddo sites and components.

Other utility wares include a sherd from a Killough Pinched vessel, two post-A.D. 1500 Belcher Ridged body sherds, and a number of sherds from punctated vessels (see Table 4). Most of the punctated sherds in the assemblage have fingernail punctated decorative elements, including one 
Weches Fingernail Impressed, var. Weches sherd with a row of crescent-shaped fingernail impressions; this vessel sherd also signifies use of the Hamp Walldan site prior to ca. A.D. 1200.

The fine ware sherds in the assemblage include three trailed sherds likely from Keno Trailed vessels, a body sherd with an exterior red-slipped surface and a curvilinear engraved line, and 30 engraved rim and body sherds (see Table 4). Two of the engraved rims have slanting scroll elements (Figure 3a), and another has horizontal engraved lines. Other distinctive engraved sherds have a cross-hatched engraved bracket element (Figure 3c), cross-hatched engraved zones; closely-spaced curvilinear engraved lines and sets of curvilinear engraved lines, including one body sherd with curvilinear engraved lines, one line of which has excised tick marks (and may be from a Poynor Engraved or Patton Engraved vessel); curvilinear hatched zones; diagonal and opposed engraved lines (Figure 3d); hatched engraved zones; a sherd with a horizontal engraved line, an open bracket element and vertical engraved lines (Figure 3e); horizontal-diagonal engraved lines and a diagonal hatched zone; a body sherd with horizontal and semicircle engraved elements (Figure 3f); opposed curvilinear engraved lines; and a body sherd with opposed curvilinear engraved lines and diagonal opposed engraved lines (Figure 3b).

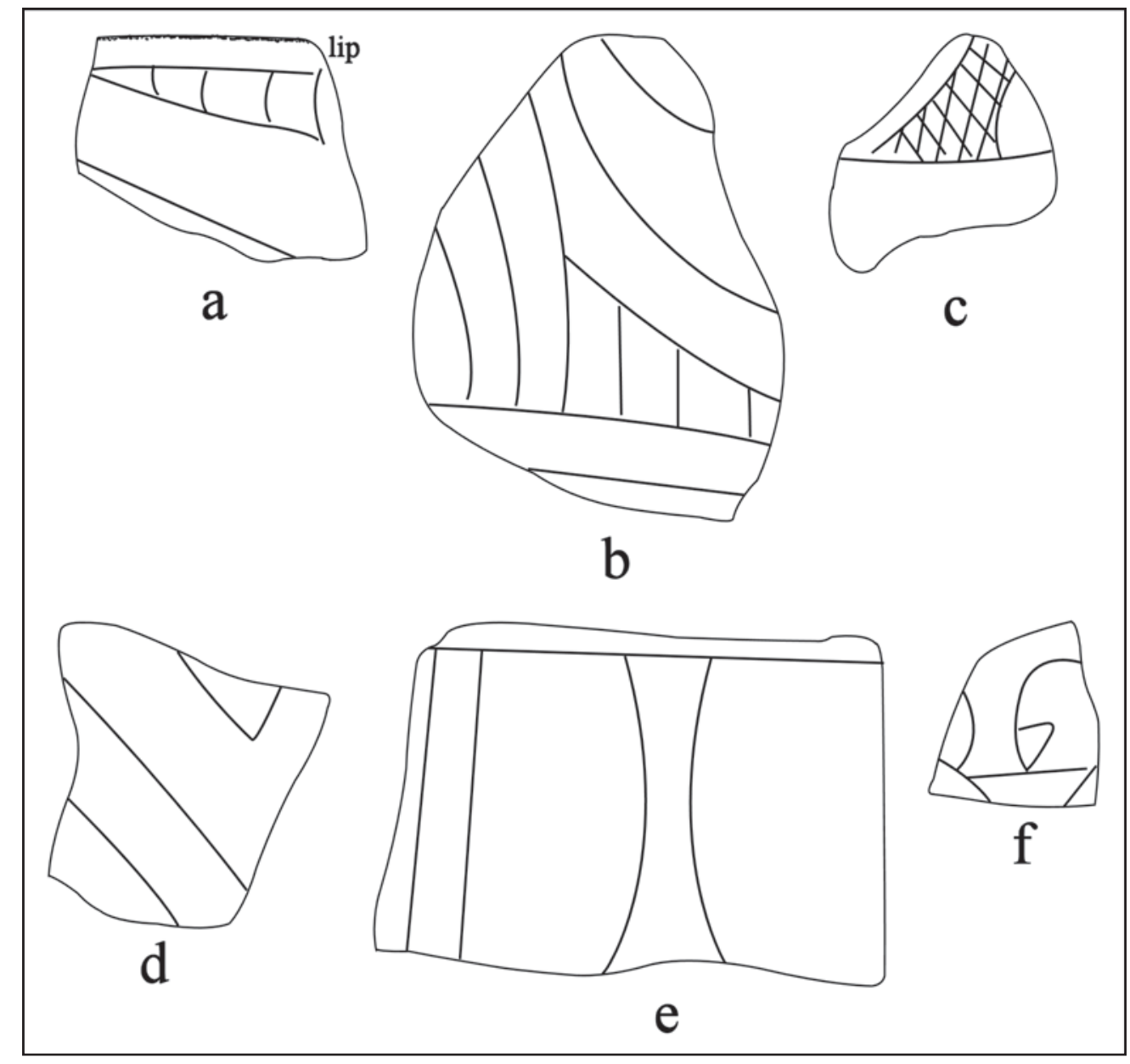

Figure 3. Selected decorative elements on fine ware engraved sherds from the Hamp Walldan site (41SA1). 
Frost Johnson Lumber Co. Site (41SA5)

Approximately 51 percent of the ceramic vessel sherds from the Frost Johnson Lumber Co. site are from bone-tempered vessels (Table 5), with comparable proportions in both the plain ware (51.6 percent) and utility ware (51.3 percent). Only 42.5 percent of the fine ware sherds are from bone-tempered vessels.

Table 5. Caddo ceramic wares at the Frost Johnson Lumber Co. site (41SA5).

\begin{tabular}{lccc}
\hline Ware & Grog-tempered & Bone-tempered & N \\
\hline Plain & 230 & 243 & 473 \\
Utility & 109 & 115 & 224 \\
Fine & 22 & 17 & 39 \\
\hline Totals & 361 & 375 & 736 \\
\hline
\end{tabular}

The plain to decorated sherd ratio in the Frost Johnson Lumber Co. site is 1.79. More than 85 percent of the decorated sherds in the assemblage are from utility ware vessels, most notably sherds from vessels with brushed, brushed-incised, brushed-incised-punctated, and brushed-punctated decorative elements (Table 6); sherds with brushed-punctated elements are particularly common in this assemblage (5.7 percent of all the decorated sherds). These various brushed sherds comprise 48.1 percent of the decorated sherds from the assemblage; rim sherds have diagonal, horizontal, vertical, and vertical-diagonal brushing marks. The brushed to plain sherd ratio is 0.27 , and the brushed to other wet paste sherds ratio is 1.12 .

Table 6. Decorative methods and elements represented in the utility ware and fine ware ceramics at the Frost Johnson Lumber Co. site (41SA5).

\begin{tabular}{llll}
\hline Ware & Rim & Body & $\mathrm{N}$ \\
\hline
\end{tabular}

Utility Ware

Appliqued

parallel appliqued ridges

straight appliqued fillet

$\begin{array}{lll}- & 1 & 1 \\ - & 1 & 1\end{array}$

\section{Brushed}

curvilinear brushed

diagonal brushed

horizontal brushed

opposed brushed

parallel brushed

vertical and diagonal brushed

$\begin{array}{lll}- & 1 & 1 \\ 1 & - & 1 \\ 1 & - & 1 \\ - & 10 & 10 \\ - & 96 & 96 \\ 1 & - & 1\end{array}$

\section{Brushed-Incised}

parallel brushed-incised marks and lines

1

Brushed-Incised-Punctated

horizontal incised line and tool punctated

zone above diagonal brushing 
Table 6. Decorative methods and elements represented in the utility ware and fine ware ceramics at the Frost Johnson Lumber Co. site (41SA5), cont.

\begin{tabular}{|c|c|c|c|}
\hline Ware & $\operatorname{Rim}$ & Body & $\mathrm{N}$ \\
\hline \multicolumn{4}{|l|}{ Brushed-Punctated } \\
\hline $\begin{array}{l}\text { horizontal brushed and fingernail punctated zone } \\
\text { and tool punctated row }\end{array}$ & - & 1 & 1 \\
\hline $\begin{array}{l}\text { horizontal brushed with tool punctated rows } \\
\text { through the brushing }\end{array}$ & 3 & - & 3 \\
\hline $\begin{array}{l}\text { opposed brushed and tool punctated row } \\
\text { through the brushing }\end{array}$ & - & 1 & 1 \\
\hline $\begin{array}{l}\text { parallel brushed and fingernail punctated row } \\
\text { through the brushing }\end{array}$ & - & 1 & 1 \\
\hline $\begin{array}{l}\text { parallel brushed and tool punctated rows } \\
\text { through the brushing }\end{array}$ & - & 8 & 8 \\
\hline $\begin{array}{l}\text { vertical brushed and tool punctated rows } \\
\text { through the brushing }\end{array}$ & 1 & - & 1 \\
\hline \multicolumn{4}{|l|}{ Incised } \\
\hline cross-hatched incised lines & 1 & - & 1 \\
\hline curvilinear incised lines & - & 1 & 1 \\
\hline diagonal incised lines & 1 & - & 1 \\
\hline diagonal opposed incised lines & 1 & 4 & 5 \\
\hline horizontal incised lines & 1 & 2 & 3 \\
\hline horizontal and diagonal incised lines & 4 & - & 4 \\
\hline parallel incised lines & - & 18 & 18 \\
\hline $\begin{array}{l}\text { parallel incised lines and hatched and cross- } \\
\text { hatched pendant triangles }\end{array}$ & - & 1 & 1 \\
\hline straight incised line & - & 11 & 11 \\
\hline vertical and diagonal incised lines & - & 1 & 1 \\
\hline \multicolumn{4}{|l|}{ Incised-Punctated } \\
\hline $\begin{array}{l}\text { circular incised zone filled with tool punctates, } \\
\text { and adjacent tool punctated row }\end{array}$ & - & 1 & 1 \\
\hline $\begin{array}{l}\text { circular and rectilinear incised zones filled } \\
\text { with circular punctates }\end{array}$ & - & 1 & 1 \\
\hline horizontal incised line above tool punctated rows & 1 & - & 1 \\
\hline $\begin{array}{l}\text { horizontal incised line below the lip and above } \\
\text { tool punctated rows }\end{array}$ & 2 & - & 2 \\
\hline horizontal incised lines above row of impressed triangle el. & - & 1 & 1 \\
\hline incised triangle el. filled with tool punctates & 2 & - & 2 \\
\hline parallel incised panels with tool punctated rows & - & 1 & 1 \\
\hline $\begin{array}{l}\text { stacked triangular incised el. filled with } \\
\text { small circular punctates }\end{array}$ & - & 1 & 1 \\
\hline straight incised line and adjacent tool punctated zone & - & 4 & 4 \\
\hline triangular incised zones filled with small circular punctates & - & 1 & 1 \\
\hline $\begin{array}{l}\text { horizontal incised line and triangular incised } \\
\text { zone filled with tool punctates }\end{array}$ & - & 1 & 1 \\
\hline
\end{tabular}


Table 6. Decorative methods and elements represented in the utility ware and fine ware ceramics at the Frost Johnson Lumber Co. site (41SA5), cont.

\begin{tabular}{llll}
\hline Ware & Rim & Body & N \\
\hline $\begin{array}{l}\text { Pinched } \\
\text { curvilinear pinched ridges } \\
\text { parallel pinched ridges }\end{array}$ & - & 1 & 1 \\
& - & 3 & 3 \\
$\begin{array}{l}\text { Punctated } \\
\text { circular punctated rows }\end{array}$ & & & \\
fingernail punctated rows & 1 & - & 1 \\
curvilinear linear tool punctated rows & - & 4 & 1 \\
linear tool punctated row/rows & - & 1 & 2 \\
opposed linear and fingernail punctated rows & - & 2 & 1 \\
tool punctated rows & - & 1 & 22
\end{tabular}

\section{Fine Ware}

\section{Engraved}

closely-spaced sets of curvilinear engraved lines

closely-spaced sets of curvilinear and parallel engraved lines cross-hatched engraved zone

curvilinear engraved lines

curvilinear scroll fill el.

diagonal engraved lines

horizontal engraved line/lines

horizontal and diagonal engraved lines

horizontal and diagonal opposed engraved lines

horizontal hatched zones and hatched bracket, with oval

panel with single horizontal engraved line

horizontal and diagonal engraved lines

narrow engraved hatched zone

opposed engraved lines

closely-spaced parallel engraved lines

parallel engraved lines

parallel and curvilinear engraved lines

scroll el. of closely-spaced curvilinear engraved lines

sets of semi-circular engraved lines

straight engraved line

straight engraved line and set of closely-

spaced curvilinear engraved lines

triangle engraved el. with curvilinear hatched lines

triangle engraved el. with hatched lines

vertical engraved lines, one with excised pendant triangle el.

vertical engraved line and diagonal opposed engraved lines

vertical engraved panels, one with a negative oval el.

vertical engraved panels with rectilinear el.

\begin{tabular}{|c|c|c|}
\hline - & 1 & 1 \\
\hline - & 1 & 1 \\
\hline - & 2 & 2 \\
\hline - & 3 & 3 \\
\hline- & 1 & 1 \\
\hline 1 & - & 1 \\
\hline 5 & - & 5 \\
\hline 1 & - & 1 \\
\hline 1 & - & 1 \\
\hline - & 1 & 1 \\
\hline 1 & - & 1 \\
\hline - & 1 & 1 \\
\hline - & 2 & 2 \\
\hline - & 4 & 4 \\
\hline - & 1 & 1 \\
\hline- & 1 & 1 \\
\hline - & 1 & 1 \\
\hline - & 1 & 1 \\
\hline - & 3 & 3 \\
\hline- & 1 & 1 \\
\hline - & 1 & 1 \\
\hline- & 1 & 1 \\
\hline 1 & - & 1 \\
\hline 1 & - & 1 \\
\hline- & 1 & 1 \\
\hline - & 1 & 1 \\
\hline 35 & 229 & 264 \\
\hline
\end{tabular}

Totals 
Other common utility wares in the site ceramic vessel sherd assemblage include those with incised (17.4 percent) (Figure 4a), tool punctated (9.9 percent), and incised-punctated (6.1 percent) (Figure 4b-e) decorative elements. The incised sherds are likely from Maydelle Incised vessels, based on rim decorative elements. One lower rim sherd has parallel or horizontal incised lines with hatched and cross-hatched pendant triangle elements (Figure 4a). The incised-punctated sherds have circular, circularrectilinear, and triangular incised zones filled with different kinds of punctations, most notably rows of small circular punctations (Figure 4c-e).

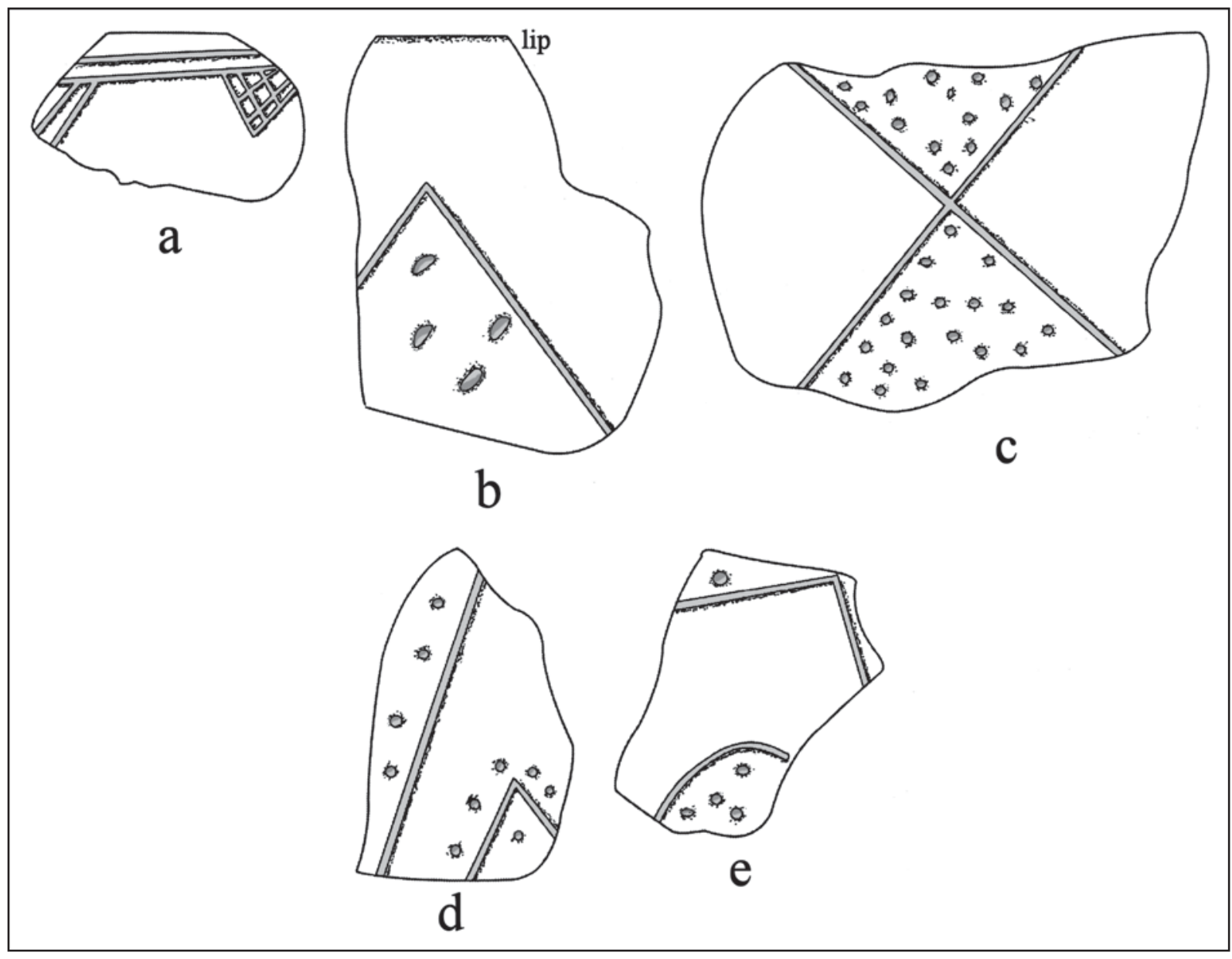

Figure 4. Selected decorative elements on utility ware sherds from the Frost Johnson Lumber Co. site (41SA5): a, incised; b-e, incised-punctated.

Other utility wares in the Frost Johnson Lumber Co. site ceramic assemblage are from Killough Pinched vessels (1.5 percent of all the decorated sherds, see Table 6) and vessels with punctated elements. These have rows of tool punctations ( 84 percent of the punctated sherd sample), fingernail punctations (13 percent), and circular punctations ( 3 percent).

Fine ware sherds account for 14.8 percent of the decorated sherd assemblage. Most of the engraved sherds have simple geometric elements, including diagonal and diagonal opposed-vertical engraved lines (Figure 5g-h), as well as vertical engraved lines; one rim has vertical engraved lines and an excised pendant triangle at the top of one of the vertical engraved lines (Figure 5k). Other engraved sherds from the Frost Johnson Lumber Co. site have portions of scroll elements and scroll fill zones (see Figure 5f, i), there are several sherds with vertical panels (Figure 5d-e), and several sherds may be from Poynor Engraved vessels with closely-spaced sets of curvilinear and parallel engraved lines (Figure 5b-c). 


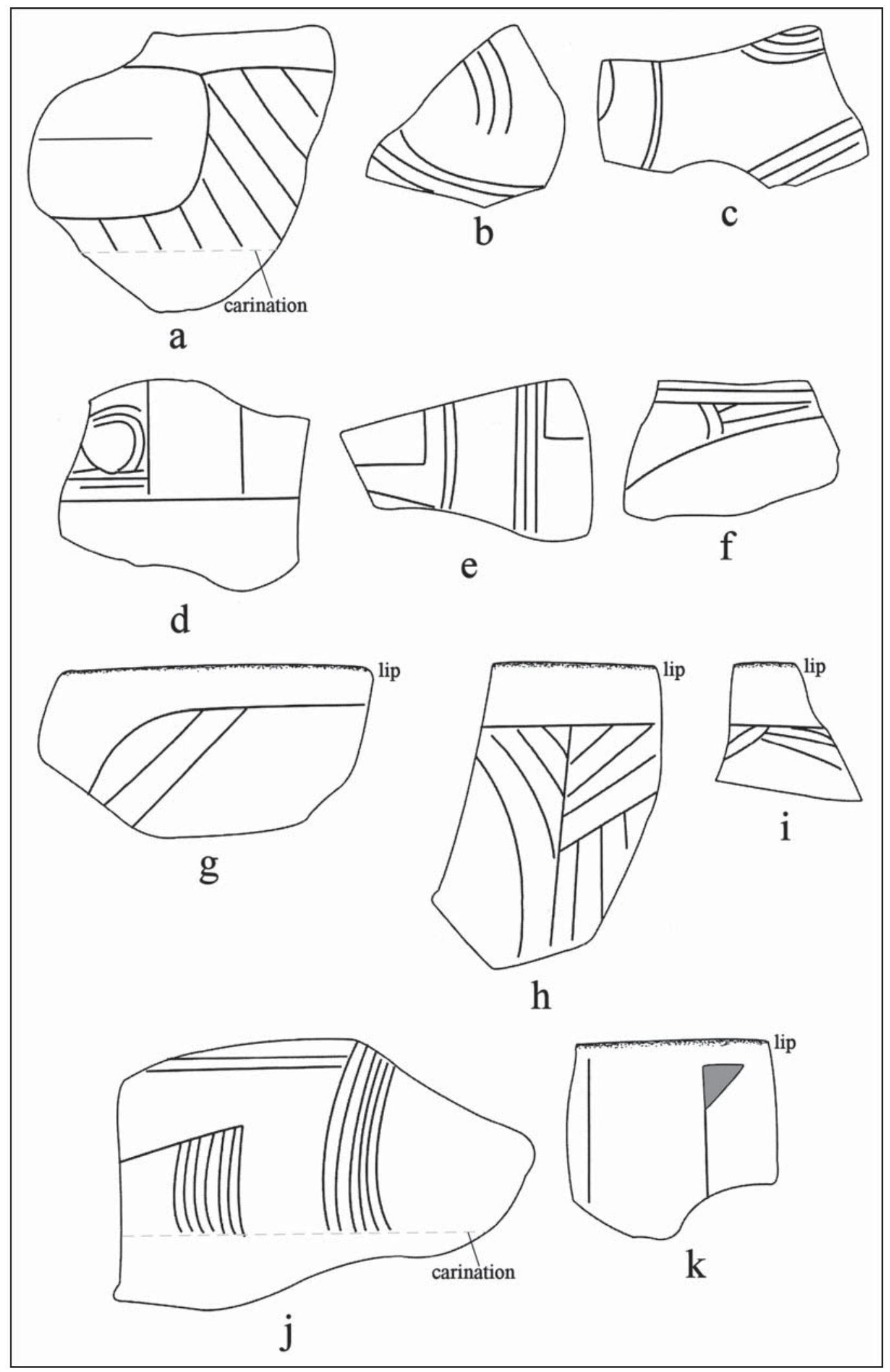

Figure 5. Selected decorative elements on fine ware engraved rim and body sherds from the Frost Johnson Lumber Co. site (41SA5). 
The most distinctive of the engraved sherds from the Frost Johnson Lumber Co. site are from Glassell Engraved carinated bowls (see Figure 5a, j; see Suhm and Jelks 1962:Plate 27). Glassell Engraved is a fine ware type most commonly found in post-A.D. 1500 Caddo sites in the Belcher phase along the Red River in northwestern Louisiana. These vessels are thus likely from a non-local ceramic source, and were not made in the Angelina River basin in East Texas.

\section{H. L. Gambles Site (41SA9)}

The ancestral Caddo ceramic vessel sherd assemblage collected by Arnold includes 342 sherds (Table 7). About 83 percent of the sherds are from grog-tempered vessels, and the remainder are from bone-tempered vessels; the highest proportion of bone-tempered sherds are in the utility wares (24.4 percent).

Table 7. Caddo ceramic wares at the H. L. Gambles site (41SA9).

\begin{tabular}{lccc}
\hline Ware & Grog-tempered & Bone-tempered & N \\
\hline Plain & 213 & 37 & 250 \\
Utility & 59 & 19 & 78 \\
Fine & 12 & 2 & 14 \\
\hline Totals & 284 & 58 & 342 \\
\hline
\end{tabular}

The plain to decorated sherd ratio in the assemblage is 2.72 , and 85 percent of the decorated sherds are from utility ware vessels. This includes vessels with incised (32.6 percent of the decorated sherds), incised-punctated (20.7 percent), and tool punctated (17.3 percent of the decorated sherd assemblage, including one lip notched vessel) decorative elements (Table 8). Sherds with brushed and brushedpunctated decorative elements comprise only 10.9 percent of the decorated sherds from the H. L. Gambles site.

Table 8. Decorative methods and elements represented in the utility ware and fine ware ceramics at the H. L. Gambles site (41SA9).

\begin{tabular}{llll}
\hline Ware & Rim & Body & $\mathrm{N}$ \\
\hline
\end{tabular}

Utility Ware

Brushed

parallel brushed

Brushed-Punctated

parallel brushed and adjacent fingernail punctated row

$\begin{array}{lll}- & 1 & 1 \\ & & \\ - & 1 & 1 \\ - & 1 & 1 \\ 2 & - & 2 \\ 1 & 2 & 3 \\ 4 & - & 4 \\ - & 1 & 1 \\ - & 1 & 1 \\ - & 3 & 3 \\ - & 14 & 14\end{array}$

Incised

curvilinear incised line

curvilinear and straight incised lines

diagonal incised lines

diagonal opposed incised lines

horizontal incised line

horizontal and diagonal opposed incised lines

opposed incised lines

parallel incised lines

straight incised line 
Table 8. Decorative methods and elements represented in the utility ware and fine ware ceramics at the H. L. Gambles site (41SA9), cont.

\begin{tabular}{|c|c|c|c|}
\hline Ware & Rim & Body & $\mathrm{N}$ \\
\hline \multicolumn{4}{|l|}{ Incised-Punctated } \\
\hline circular incised zone filled with tool punctates & - & 1 & 1 \\
\hline $\begin{array}{l}\text { circular incised zone filled with small circular } \\
\text { punctates and associated curvilinear incised lines }\end{array}$ & - & 1 & 1 \\
\hline curvilinear incised panels filled with tool punctates & 1 & - & 1 \\
\hline diagonal incised panels filled with tool punctates & 1 & - & 1 \\
\hline incised triangle el. filled with tool punctates & - & 3 & 3 \\
\hline straight incised line and adjacent tool punctated zone & - & 10 & 10 \\
\hline vertical incised panels with tool punctated rows & 1 & - & 1 \\
\hline \multicolumn{4}{|l|}{ Punctated } \\
\hline fingernail punctated rows & - & 4 & 4 \\
\hline tool punctated rows & 1 & 14 & 15 \\
\hline \multicolumn{4}{|l|}{ Punctated-Lip Notched } \\
\hline tool punctated rows and lip notching & 1 & - & 1 \\
\hline \multicolumn{4}{|l|}{ Fine Ware } \\
\hline \multicolumn{4}{|l|}{ Engraved } \\
\hline curvilinear hatched zone and hatched triangle el. & - & 1 & 1 \\
\hline hatched triangular el. & - & 1 & 1 \\
\hline $\begin{array}{l}\text { hatched triangle el. and narrow zone with } \\
\text { closely-spaced parallel engraved lines }\end{array}$ & - & 1 & 1 \\
\hline hatched and diagonal opposed zones & - & 1 & 1 \\
\hline horizontal and curvilinear engraved lines & 1 & - & 1 \\
\hline narrow hatched zones & - & 1 & 1 \\
\hline narrow opposed hatched zones & - & 1 & 1 \\
\hline parallel engraved lines & - & 4 & 4 \\
\hline straight engraved line & - & 2 & 2 \\
\hline \multicolumn{4}{|l|}{ Trailed } \\
\hline parallel trailed lines & - & 1 & 1 \\
\hline Totals & 13 & 79 & 92 \\
\hline
\end{tabular}

The incised rim and body sherds from the site feature diagonal, diagonal opposed, and horizontal elements (Figure 6a-b); a few body sherds also have curvilinear incised decorative elements (see Table 8). The incised-punctated sherds, probably from Pineland Punctated-Incised vessels (see Jelks 1965), have incised panels, circles, and triangle incised elements that are filled primarily with tool punctations (Figure 6c-f).

Eighty percent of the sherds from punctated vessels have rows of tool punctations as the decorative element (see Table 8). One punctated rim also has been lip notched (see Table 8). 


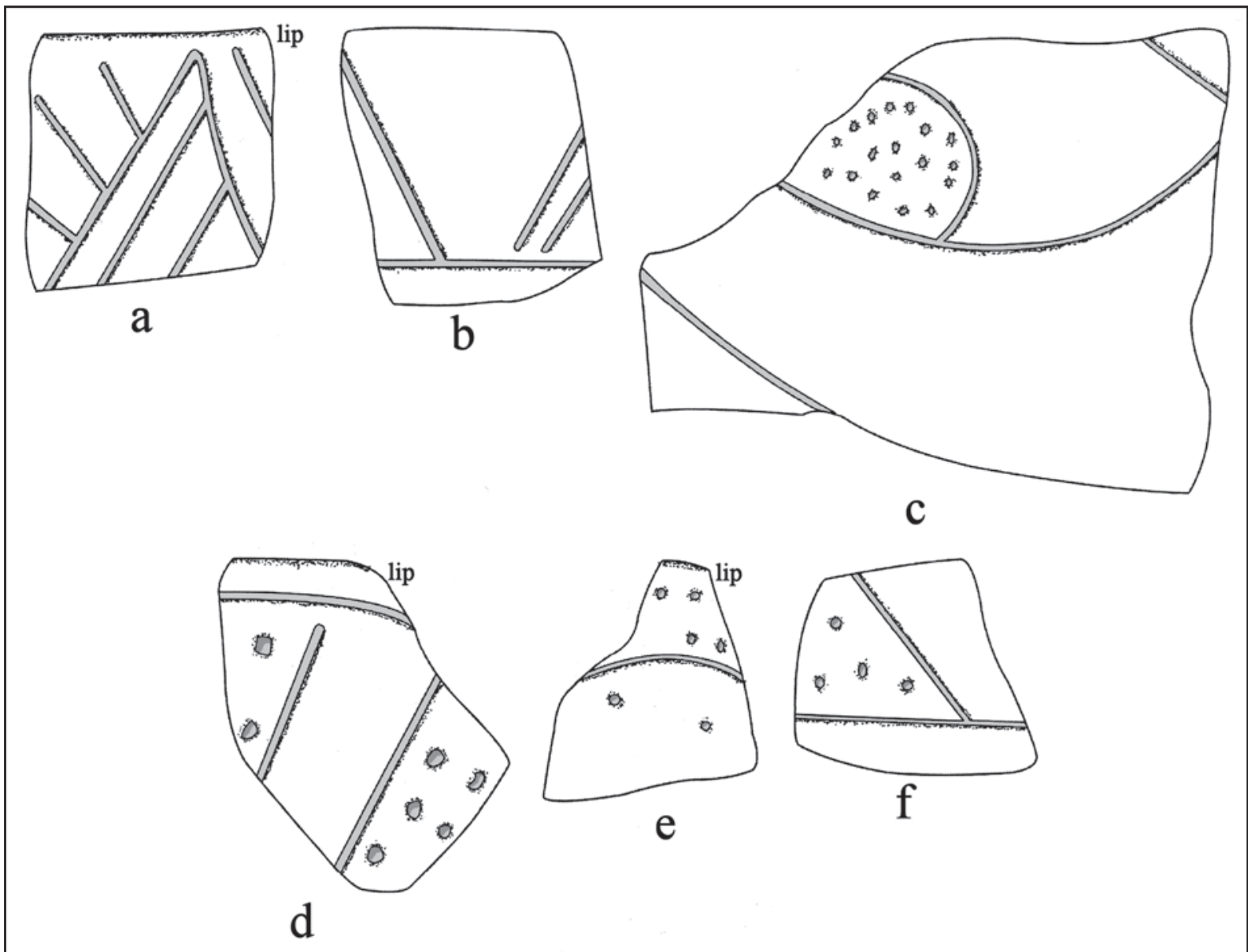

Figure 6. Selected utility ware decorative elements in the H. L. Gambles site (41SA9) ceramic assemblage: a-b, incised; c-f, incised-punctated.

A number of the engraved sherds in the H. L. Gambles site ceramic assemblage have straight or curvilinear hatched engraved zones of varying widths (Figure 7a, d-f). The curvilinear hatched sherd closely resembles a carinated bowl rim sherd from the Sawmill site, on Harvey Creek near its confluence with the Angelina River, at Lake Sam Rayburn (Jelks 1965:Figure 62h). Another engraved sherd has a triangle element filled with curvilinear hatched lines (Figure 7c), and an engraved rim has a horizontal panel filled with curvilinear engraved lines (Figure 7b). 


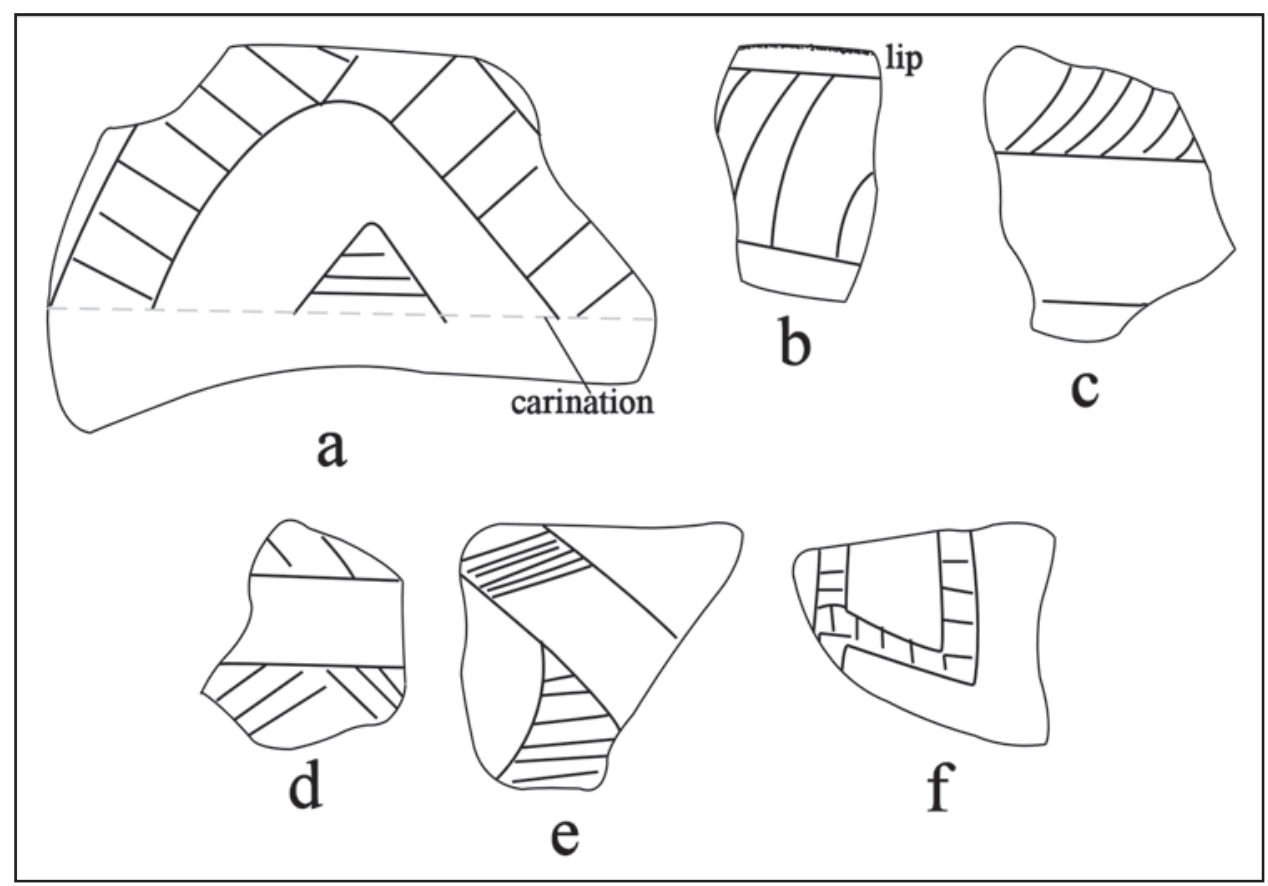

Figure 7. Selected engraved fine ware decorative elements in the H. L. Gambles site (41SA9) ceramic assemblage.

\section{Drew War Site (41SA11)}

The ancestral Caddo ceramic sherd assemblage from the Drew War site includes sherds from grogtempered ( 50.7 percent), bone-tempered ( 48.7 percent), and shell-tempered ( 0.5 percent) vessels (Table 9). The highest proportion of bone-tempered sherds is in the fine wares (61.5 percent), although the sample of fine ware sherds is small; the few shell-tempered sherds are in the utility ware and plain ware.

Table 9. Caddo ceramic wares at the Drew War Site (41SA11).

\begin{tabular}{lcccc}
\hline Ware & Grog-tempered & Bone-tempered & Shell-tempered & N \\
\hline Plain & 94 & 74 & 1 & 169 \\
Utility & 173 & 176 & 2 & 351 \\
Fine & 10 & 16 & - & 26 \\
\hline Totals & 277 & 266 & 3 & 546 \\
\hline
\end{tabular}

The plain to decorated sherd ratio in the War site assemblage is 0.45 , and about 93 percent of the decorated sherds are from utility wares. Sherds from vessels with brushed and brushed-incised decorative elements account for 63.4 percent of the decorated sherd assemblage (Table 10); one of the brushed-incised sherds may be from a Spradley Brushed-Incised vessel. Sherds with incised decorative elements comprise another 23.3 percent of the decorated sherd assemblage, followed by fine ware vessel sherds with engraved and trailed decorative elements ( 7.0 percent). 
Table 10. Decorative methods and elements represented in the utility ware and fine ware ceramics at the Drew War site (41SA11).

\begin{tabular}{llll}
\hline Ware & Rim & Body & $\mathrm{N}$ \\
\hline
\end{tabular}

\section{Utility Ware}

\section{Appliqued}

curvilinear appliqued fillets

straight appliqued fillet

\section{Appliqued-Incised}

circular appliqued node with curvilinear incised

$-1$

lines around the node

diagonal incised lines and circular appliqued node vertical appliqued ridge and diagonal opposed

incised lines

\section{Brushed}

diagonal brushed

horizontal brushed

horizontal and vertical brushed

opposed brushed

parallel brushed

$\begin{array}{lll}- & 1 & 1 \\ - & 1 & 1\end{array}$

1

1

vertical brushed

$\begin{array}{lll}2 & - & 2 \\ 7 & - & 7 \\ - & 1 & 1 \\ - & 5 & 5 \\ - & 218 & 218 \\ 4 & - & 4\end{array}$

\section{Brushed-Incised}

parallel brushed and overlying opposed incised lines

parallel brushed-incised marks and lines

\section{Incised}

curvilinear incised lines

curvilinear and parallel incised lines

diagonal incised lines

diagonal opposed incised lines

hatched triangle incised el.

horizontal incised lines

horizontal and diagonal incised lines

parallel incised lines

closely-spaced parallel incised lines

straight incised line

vertical incised lines

vertical and diagonal opposed incised lines

\section{Incised-Punctated}

closely-spaced parallel incised lines and

1


Table 10. Decorative methods and elements represented in the utility ware and fine ware ceramics at the Drew War site (41SA11), cont.

\begin{tabular}{llll}
\hline Ware & Rim & Body & N \\
\hline $\begin{array}{l}\text { Pinched } \\
\text { parallel pinched ridges }\end{array}$ & - & 4 & 4 \\
$\begin{array}{l}\text { Punctated } \\
\text { fingernail punctated rows } \\
\text { tool punctated rows }\end{array}$ & - & 3 & 3 \\
$\begin{array}{l}\text { Ridged } \\
\text { parallel ridged }\end{array}$ & 1 & 6 & 7 \\
\end{tabular}

\section{Fine Ware}

\section{Engraved}

circular and triangular engraved el.

curvilinear engraved lines

curvilinear and straight engraved lines

diagonal opposed engraved lines

excised triangle on the rim; vertical incised

lines on the body

hatched engraved zone

horizontal-diagonal engraved lines and excised bracket

horizontal and diagonal engraved lines and

hatched diagonal zone

horizontal engraved line and hatched triangle el.

opposed engraved lines

oval engraved el.

parallel engraved lines

scroll el.

scroll el. with hatched triangle el.

straight engraved line

$\begin{array}{lll}- & 1 & 1 \\ - & 1 & 1 \\ - & 1 & 1 \\ - & 4 & 4 \\ - & 1 & 1 \\ - & & \\ - & 2 & 2 \\ 1 & - & 1 \\ 1 & - & 1 \\ & & \\ 1 & 1 & 2 \\ - & 1 & 1 \\ 1 & - & 1 \\ - & 5 & 1 \\ - & 1 & 1 \\ - & 1 & 1 \\ - & 1 & \end{array}$

\section{Trailed}

curvilinear trailed lines

straight trailed line

\begin{tabular}{ccc}
- & 1 & 1 \\
- & 1 & 1 \\
\hline 23 & 354 & 377
\end{tabular}

Totals



The incised rim sherds have diagonal, horizontal, horizontal-diagonal, and vertical incised decorative elements (see Table 10). The punctated sherds in the assemblage primarily have rows of tool punctations, and other utility wares include body sherds from post-A.D. 1400/1500 Killough Pinched (1.1 percent of the decorated sherds) and Belcher Ridged, var. Belcher (1.1 percent) vessels. Rim and body sherds with appliqued fillets, nodes, and ridge decorative elements (1.3 percent of the decorated sherd assemblage) are present in the Drew War site assemblage, including one rim with diagonal incised lines (pitched from left to right) and a large circular appliqued node (Figure 8). Incised-punctated sherds account for only 0.5 percent of the decorated sherd assemblage. 


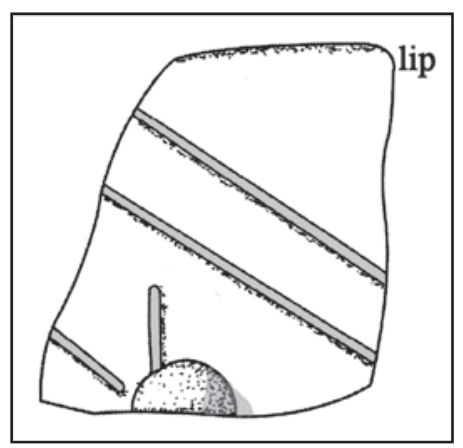

Figure 8. Appliqued-incised rim sherd from the Drew War site (41SA11) utility wares.

The sherds with trailed decorative elements ( 0.5 percent of the decorated sherds in the assemblage) are likely from Keno Trailed vessels, probably bowls. The engraved sherds have scroll elements or portions of slanting scroll elements, one with a vertical excised bracket (Figure 9a, f-g). Other sherds in the assemblage have narrow hatched panels (Figure 9c) or hatched triangle elements (Figure 9b, d), and one has both circular and triangular elements (Figure 9e). One distinctive carinated bowl sherd has an excised triangle element on the rim panel and vertical incised lines on the vessel body.

\section{E. D. Kinon Place III Site (41SA15)}

A total of 410 ancestral Caddo ceramic vessel sherds are in the assemblage from the E. D. Kinon Place III site (Table 11). About 55 percent of the sherds are from grog-tempered vessels, and the remainder are from bone-tempered vessels; the highest proportion of bone-tempered sherds (51 percent) are in the utility wares. Only 25 percent of the fine ware engraved sherds are from bone-tempered vessels.

Table 11. Caddo ceramic wares at the E. D. Kinon Place III Site (41SA15).

\begin{tabular}{lccc}
\hline Ware & Grog-tempered & Bone-tempered & N \\
\hline Plain & 93 & 54 & 147 \\
Utility & 123 & 128 & 251 \\
Fine & 9 & 3 & 12 \\
\hline Totals & 225 & 185 & 410 \\
\hline
\end{tabular}

The plain to decorated sherd ratio in the assemblage is 0.56 , and more than 95 percent of the decorated sherds are from brushed vessels (Table 12). Sherds from brushed vessels, or with brushedincised and brushed-punctated decorative elements, comprise 81 percent of all the decorated sherds from the site; the brushed to plain sherd ratio is 1.46 , and the brushed to other wet paste sherds ratio is 5.1. The brushed-incised sherds have parallel brushing marks and overlying incised elements, and may be from Spradley Brushed-Incised vessels. 


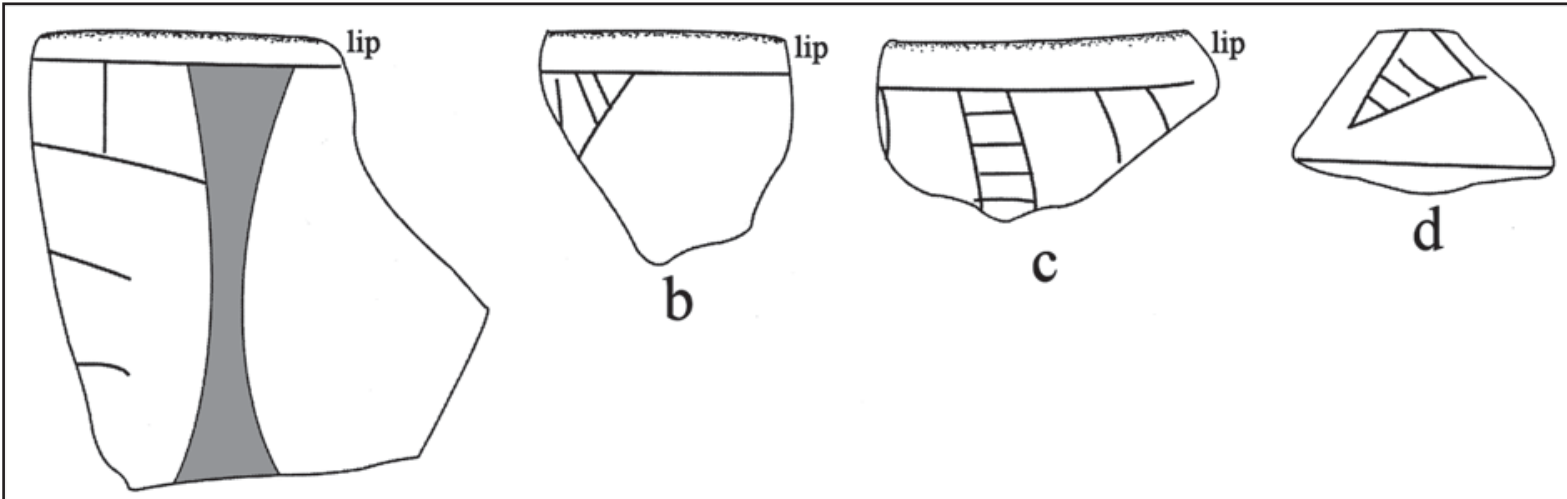

a
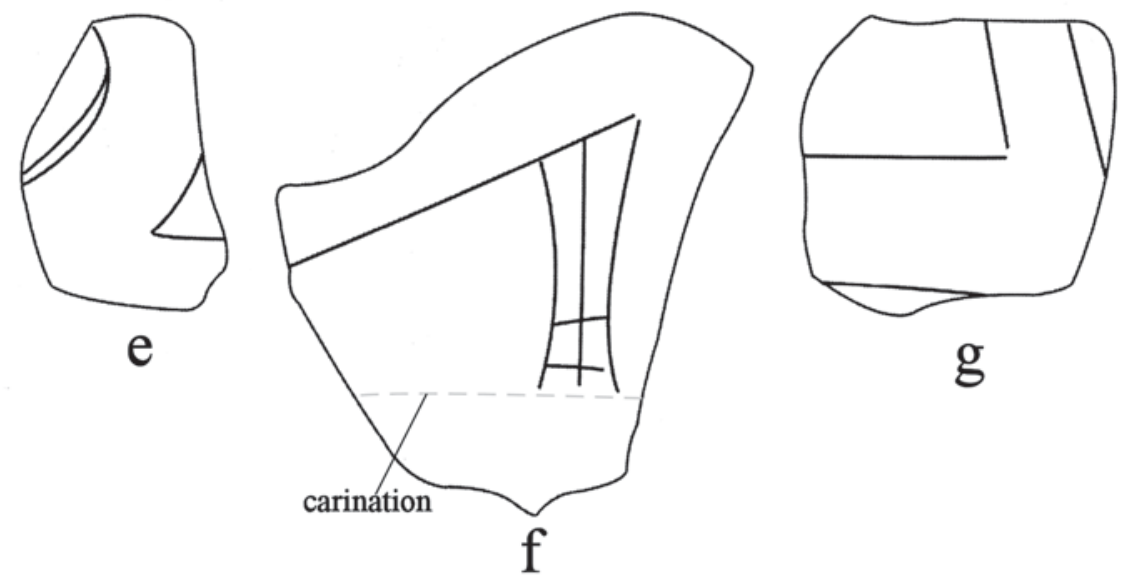

Figure 9. Selected decorative elements on engraved fine ware sherds from the Drew War site (41SA11).

Table 12. Decorative methods and elements represented in the utility ware and fine ware ceramics at the E. D. Kinon Place III site (41SA15).

\begin{tabular}{llll}
\hline Ware & Rim & Body & N \\
\hline
\end{tabular}

\section{Utility Ware}

\section{Appliqued}

horizontal and diagonal appliqued fillets

1

\section{Brushed}

horizontal brushed

opposed brushed

overlying brushed

parallel brushed

$\begin{array}{lll}5 & - & 5 \\ - & 4 & 4 \\ - & 1 & 1 \\ - & 199 & 199\end{array}$

\section{Brushed-Incised}

parallel brushed and overlying curvilinear

$-$

1

incised line

parallel brushed and overlying diagonal incised

$\begin{array}{ll}- & 1\end{array}$

lines

parallel brushed and overlying straight incised 
Table 12. Decorative methods and elements represented in the utility ware and fine ware ceramics at the E. D. Kinon Place III site (41SA15), cont.

\begin{tabular}{|c|c|c|c|}
\hline Ware & $\operatorname{Rim}$ & Body & $\mathrm{N}$ \\
\hline \multicolumn{4}{|l|}{ Brushed-Punctated } \\
\hline $\begin{array}{l}\text { parallel brushed with tool punctated row through } \\
\text { the brushing }\end{array}$ & - & 1 & 1 \\
\hline tool punctated row above vertical brushing marks & - & 1 & 1 \\
\hline \multicolumn{4}{|l|}{ Incised } \\
\hline curvilinear incised lines & - & 1 & 1 \\
\hline diagonal incised lines & 1 & - & 1 \\
\hline horizontal-diagonal incised lines & 1 & - & 1 \\
\hline opposed incised lines & - & 2 & 2 \\
\hline parallel incised lines & - & 15 & 15 \\
\hline straight incised line & - & 3 & 3 \\
\hline \multicolumn{4}{|l|}{ Incised-Punctated } \\
\hline $\begin{array}{l}\text { straight incised line and adjacent fingernail } \\
\text { punctated zone }\end{array}$ & - & 1 & 1 \\
\hline \multicolumn{4}{|l|}{ Pinched } \\
\hline concentric circular pinched ridges & - & 1 & 1 \\
\hline parallel pinched ridges & - & 1 & 1 \\
\hline straight pinched ridge & - & 1 & 1 \\
\hline \multicolumn{4}{|l|}{ Punctated } \\
\hline circular punctated rows & - & 1 & 1 \\
\hline tool punctated row below the lip & 1 & - & 1 \\
\hline tool punctated rows & - & 6 & 6 \\
\hline tool punctated rows, opposed & - & 1 & 1 \\
\hline
\end{tabular}

\section{Fine Ware}

\section{Engraved}

curvilinear cross-hatched zones

curvilinear engraved lines

curvilinear engraved lines, closely-spaced

hatched engraved zone

horizontal engraved and hatched curvilinear zone

parallel engraved lines

scroll el.

straight engraved line

vertical engraved lines, closely-spaced

Totals

\begin{tabular}{lll}
- & 1 & 1 \\
- & 3 & 3 \\
- & 1 & 1 \\
- & 1 & 1 \\
1 & - & 1 \\
- & 1 & 1 \\
- & 1 & 1 \\
- & 2 & 2 \\
- & 1 & 1 \\
\hline 9 & 254 & 263
\end{tabular}

Sherds from incised vessels account for 8.8 percent of the decorated sherds at the site, followed by sherds with punctated decorative elements (3.4 percent). One distinctive incised rim sherd has horizontal and diagonal lines (Figure 10a). Sherds from punctated vessels primarily have rows of tool punctations. There are also three Killough Pinched body sherds (1.1 percent of the decorated sherds) in the 
assemblage, a single zone incised-punctated body sherd, and a body sherd with horizontal and diagonal appliqued fillets (see Table 12).

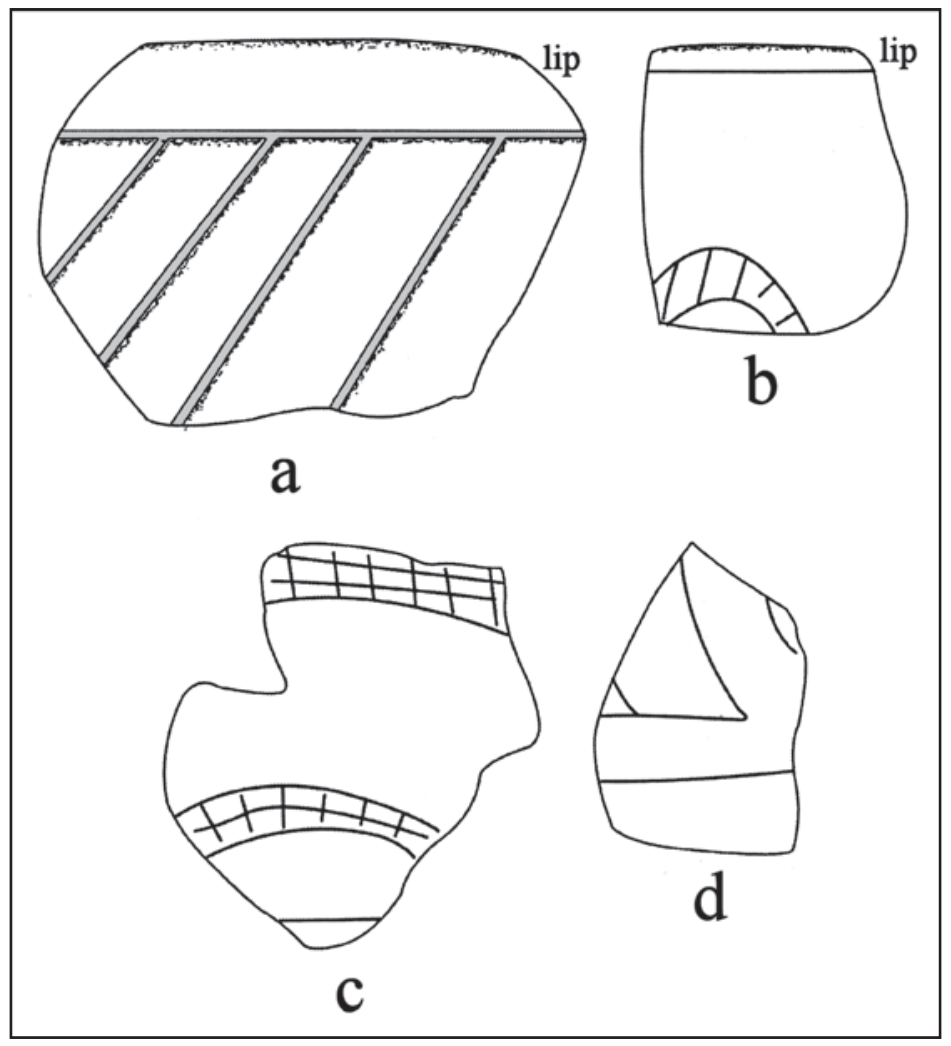

Figure 10. Selected decorative elements on utility ware and fine ware sherds from 41SA15.

The engraved sherds from the site have hatched and cross-hatched curvilinear engraved zones (see Figure 10b-c), including one rim sherd, as well as a scroll element (see Figure 10d) on another sherd from the site. One body sherd in the collection has vertical engraved lines.

\section{E. D. Kinon Place IV Site (41SA16)}

A large assemblage of ancestral Caddo ceramic vessel sherds $(n=722)$ was collected by Arnold from the E. D. Kinon Place IV site (Table 13). About 62 percent of the sherds are from grog-tempered vessels, and the remaining 37.8 percent are from bone-tempered vessels. The highest proportion of bonetempered vessel sherds occur in the utility wares ( 45.9 percent).

Table 13. Caddo ceramic wares at the E. D. Kinon Place IV site (41SA16).

\begin{tabular}{lccc}
\hline Ware & Grog-tempered & Bone-tempered & N \\
\hline Plain & 226 & 94 & 320 \\
Utility & 197 & 167 & 364 \\
Fine & 26 & 12 & 38 \\
\hline Totals & 449 & 273 & 722 \\
\hline
\end{tabular}


About 90.5 percent of the decorated sherd assemblage is from utility ware vessels. The plain to decorated sherd ratio in the assemblage is 0.80 , and 59.5 percent of the decorated sherds have brushing marks, either as the sole decorative element or in combination with brushed-incised, brushed-appliqued (Pease Brushed-Incised), brushed-punctated, and brushed-punctated-appliqued (Figure 11a) decorative elements (Table 14). The brushed to plain sherd ratio is 0.74 , and the ratio of brushed to other wet paste sherds is 1.59 . Several of the brushed-incised sherds have parallel brushing marks and overlying incised lines, and may be from Spradley Brushed-Incised vessels.

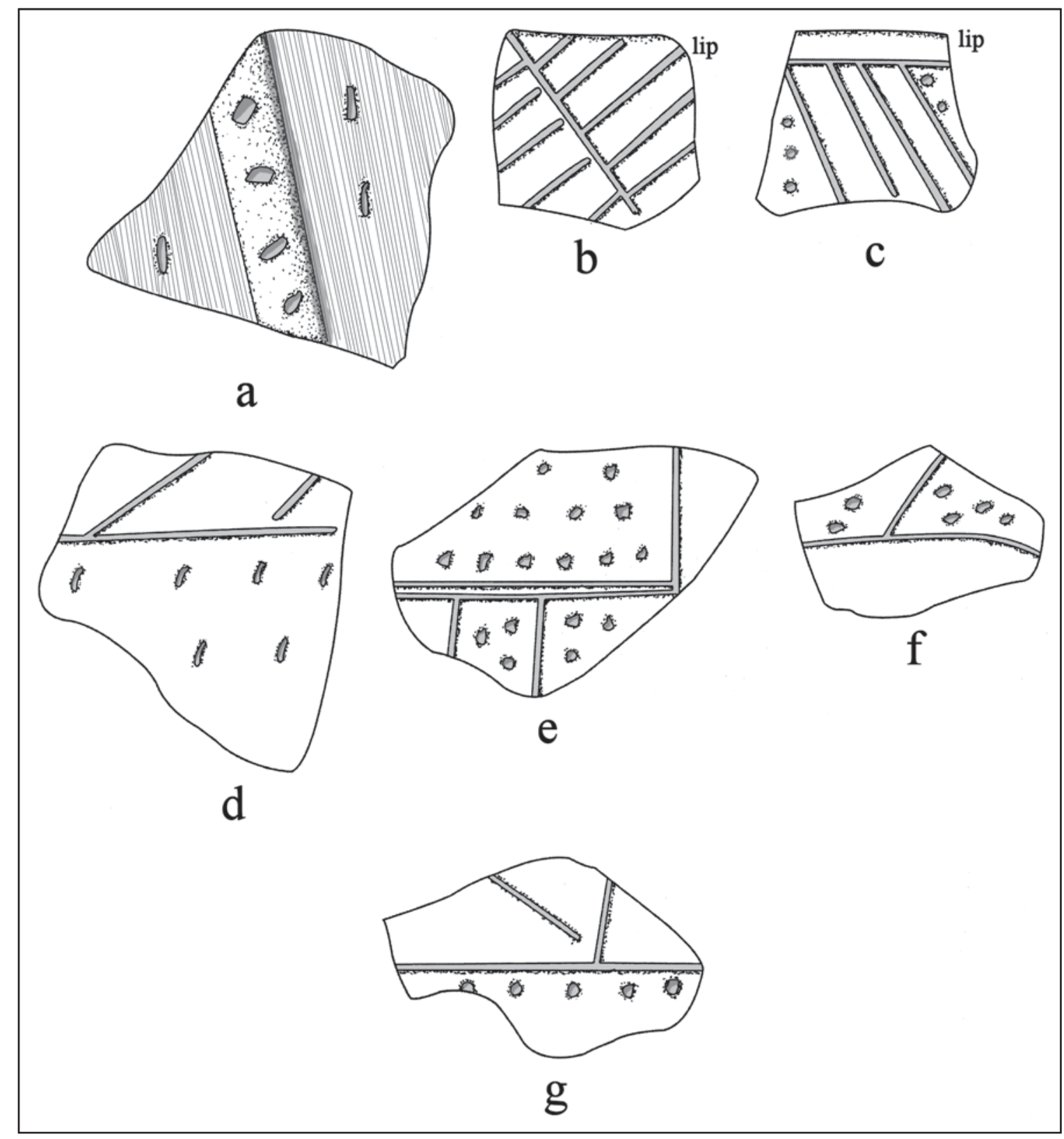

Figure 11. Selected decorative elements on utility ware sherds from the E. D. Kinon Place IV site (41SA16): a, brushed-punctated-appliqued; b, incised; c-g, incised-punctated. 
Table 14. Decorative methods and elements represented in the utility ware and fine ware ceramics at the E. D. Kinon Place IV site (41SA16).

\begin{tabular}{llll}
\hline Ware & Rim & Body & $\mathrm{N}$ \\
\hline
\end{tabular}

\section{Utility Ware}

\section{Brushed}

diagonal brushed

horizontal brushed

opposed brushed

overlapping brushed

parallel brushed

vertical brushed

$\begin{array}{lll}1 & 1 & 2 \\ 4 & - & 4 \\ - & 4 & 4 \\ - & 1 & 1 \\ - & 203 & 203 \\ 1 & - & 1\end{array}$

\section{Brushed-Appliqued}

opposed parallel brushed and straight appliqued fillet parallel brushed and straight appliqued fillet

\section{Brushed-Appliqued-Punctated}

parallel brushed, straight appliqued fillet, and

fingernail punctates through the brushing

\section{Brushed-Incised}

parallel brushed-incised marks and lines

parallel brushed with overlying diagonal incised lines

parallel brushed with overlying opposed parallel

incised lines

parallel brushed with overlying opposed straight line

\section{Brushed-Punctated}

curvilinear brushed and tool punctated row

through the brushing

horizontal brushed with tool punctated row

through the brushing

horizontal brushed with tool punctated row

beneath the lip

parallel brushed and adjacent tool punctated row

parallel brushed and tool punctated row

through the brushing

\section{Incised}

cross-hatched incised lines

diagonal incised lines

diagonal opposed incised lines

horizontal incised lines

horizontal and diagonal incised lines

horizontal and vertical incised lines

opposed incised lines

parallel incised lines

straight incised line

$\begin{array}{lll}- & 2 & 2 \\ - & 2 & 2 \\ - & 1 & 1 \\ - & 1 & 1 \\ & & \\ - & 1 & 1 \\ & & \\ 1 & - & 1 \\ & & \\ 2 & - & 2 \\ & & \\ - & 1 & 1 \\ - & 4 & 4 \\ & & \\ & & \\ & & 3 \\ - & 3 & 4 \\ 4 & - & 2 \\ 1 & 1 & 5 \\ 5 & - & 1 \\ 1 & - & 1 \\ 1 & - & 4 \\ - & 4 & 22 \\ - & 22 & 17 \\ - & 17 & \end{array}$


Table 14. Decorative methods and elements represented in the utility ware and fine ware ceramics at the E. D. Kinon Place IV site (41SA16), cont.

\begin{tabular}{|c|c|c|c|}
\hline Ware & Rim & Body & $\mathrm{N}$ \\
\hline \multicolumn{4}{|l|}{ Incised-Punctated } \\
\hline circular incised zone filled with tool punctates & - & 1 & 1 \\
\hline diagonal incised lines and tool punctated row & - & 1 & 1 \\
\hline diagonal incised panel filled with tool punctates & - & 1 & 1 \\
\hline $\begin{array}{l}\text { diagonal opposed and horizontal incised lines } \\
\text { above a tool punctated row }\end{array}$ & - & 1 & 1 \\
\hline horizontal incised line above tool punctated zone & 1 & - & 1 \\
\hline $\begin{array}{l}\text { horizontal and diagonal incised lines above } \\
\text { fingernail punctated rows }\end{array}$ & - & 1 & 1 \\
\hline $\begin{array}{l}\text { horizontal incised line and incised triangle el } \\
\text { filled with circular punctates }\end{array}$ & 1 & - & 1 \\
\hline $\begin{array}{l}\text { horizontal incised line and incised triangle el. } \\
\text { filled with tool punctates }\end{array}$ & 1 & - & 1 \\
\hline $\begin{array}{l}\text { opposed rectilinear incised panels filled with } \\
\text { tool punctates }\end{array}$ & - & 1 & 1 \\
\hline parallel incised lines and adjacent tool punctated zone & - & 2 & 2 \\
\hline $\begin{array}{l}\text { straight incised line and adjacent linear tool } \\
\text { punctated zone }\end{array}$ & - & 1 & 1 \\
\hline straight incised line and adjacent tool punctated zone & - & 6 & 6 \\
\hline triangular incised el. filled with circular punctates & - & 1 & 1 \\
\hline \multicolumn{4}{|l|}{ Pinched } \\
\hline parallel pinched ridges & - & 5 & 5 \\
\hline straight pinched ridge & - & 1 & 1 \\
\hline \multicolumn{4}{|l|}{ Punctated } \\
\hline fingernail punctated rows & 1 & 13 & 14 \\
\hline linear tool punctated rows & - & 1 & 1 \\
\hline opposed linear tool punctated rows & - & 1 & 1 \\
\hline tool punctated rows & 4 & 22 & 26 \\
\hline
\end{tabular}

Fine Ware

\section{Engraved}

concentric circles engraved lines and hooked arm el. concentric semi-circle el.

cross-hatched engraved zone

curvilinear engraved lines

curvilinear excised zones and curvilinear engraved lines curvilinear hatched zone diagonal engraved lines diagonal and diagonal curvilinear engraved lines

$\begin{array}{lll}- & 1 & 1 \\ - & 1 & 1 \\ 1 & - & 1 \\ - & 11 & 11 \\ - & 3 & 3 \\ - & 1 & \\ 1 & - & 1 \\ 1 & - & 1\end{array}$


Table 14. Decorative methods and elements represented in the utility ware and fine ware ceramics at the E. D. Kinon Place IV site (41SA16), cont.

\begin{tabular}{llll}
\hline Ware & Rim & Body & N \\
\hline Engraved, cont. & & & 3 \\
narrow hatched zone & - & 3 & 1 \\
hatched triangle el. & - & 1 & 2 \\
horizontal engraved lines & 1 & 1 & 1 \\
horizontal engraved lines and hatched triangle el. & - & 1 & 2 \\
horizontal and diagonal engraved lines & 1 & 1 & 1 \\
horizontal and vertical engraved lines & - & 1 & 1 \\
opposed curvilinear engraved lines and hatched & - & 1 & 1 \\
$\quad$ curvilinear zone & & & 3 \\
opposed engraved lines & - & 1 & 1 \\
parallel engraved lines & - & 3 & 1 \\
scroll el. & - & 1 & 402 \\
straight engraved line & - & 1 & 368 \\
\hline Totals & 34 & & \\
\hline
\end{tabular}

Sherds from vessels decorated with incised lines comprise 14.8 percent of the decorated sherds, and sherds with either fingernail or tool punctated elements account for 10.5 percent of the decorated sherd assemblage (see Table 14). The incised rim sherds have diagonal incised, diagonal opposed incised lines (see Figure 11b), horizontal incised, horizontal and diagonal incised, and horizontal and vertical incised lines. The punctated sherds have fingernail and tool punctated elements. Incised-punctated sherds are relatively common in the E. D. Kinon Place IV site assemblage, comprising 4.8 percent of the decorated sherds (see Table 14), and these sherds have incised triangles, circles, and panels filled primarily with tool punctations (see Figure 11c-g). Other utility wares in the assemblage include six body sherds from Killough Pinched vessels.

Engraved sherds in the ceramic assemblage feature hatched zones (Figure 12a) and hatched triangles, concentric circles and semi-circles (Figure 12d) or concentric circles and a hooked arm element (Figure 12b), and slanting scroll elements (Figure 12c), as well as rims with diagonal, horizontal, horizontaldiagonal engraved lines, as well as cross-hatched engraved zones (see Table 14). Three distinctive body sherds in the assemblage have curvilinear engraved lines and curvilinear excised zones (Figure 12e-g).

\section{Allan Howill Site (41SA24)}

The plain and decorated ceramic vessel sherds in the Allan Howill site assemblage are from grogtempered (60.2 percent), bone-tempered (39.5 percent), and shell-tempered ( 0.2 percent) vessels (Table 15); of the 14 sites discussed in this article, only the Hanks site (41SA80) in the Ayish Bayou drainage and the Drew War site (41SA11) in the Patroon Bayou drainage have any sherds from shell-tempered vessels, and the proportions ( 0.4 percent) are likewise rather low across these assemblages. The highest proportion of bone-tempered sherds is in the fine wares (52.9 percent). 


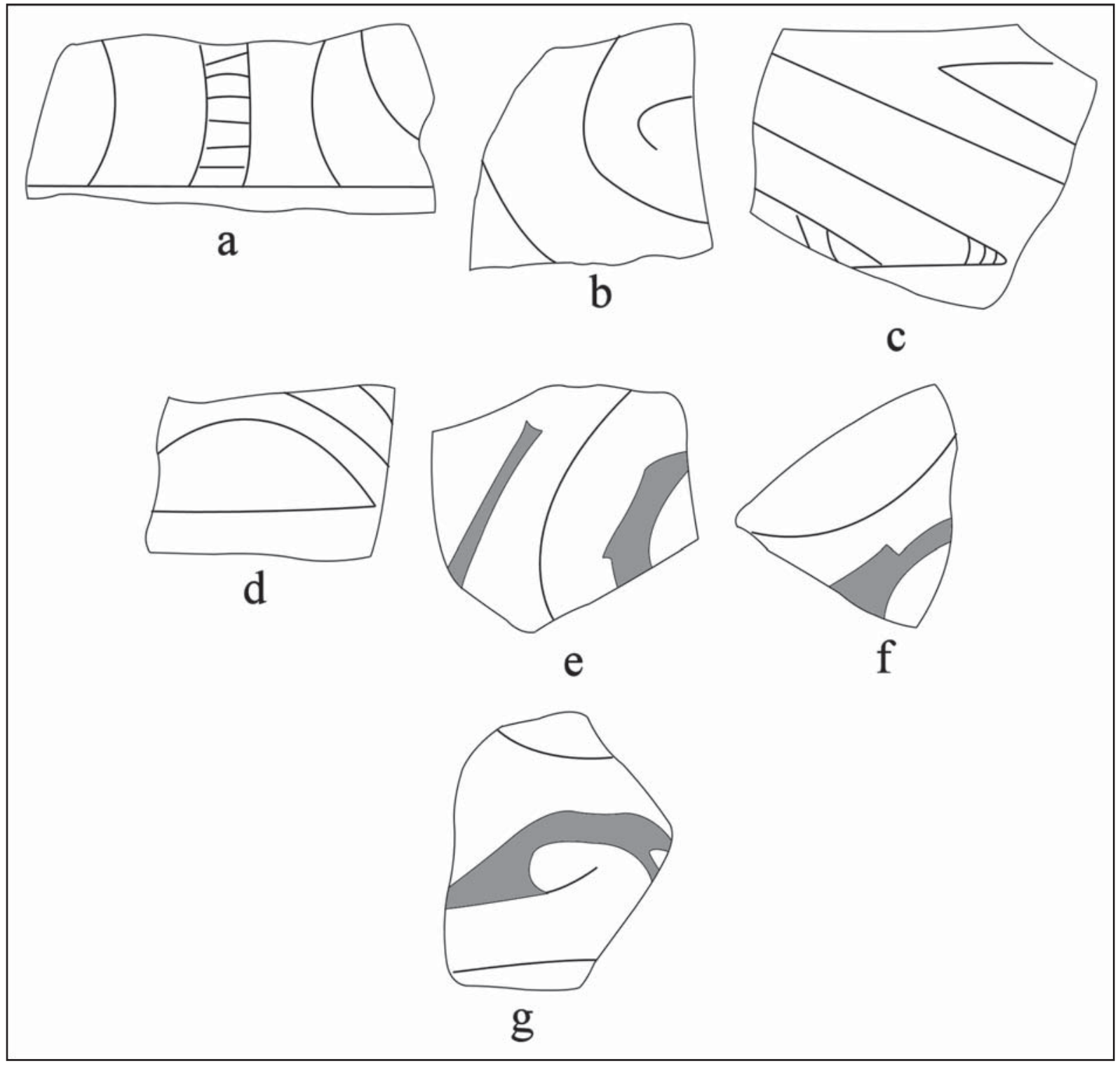

Figure 12. Selected decorative elements in the engraved fine ware sherds from the E. D. Kinon Place IV site (41SA16).

Table 15. Caddo ceramic wares at the Allan Howill site (41SA24).

\begin{tabular}{lcccc}
\hline Ware & Grog-tempered & Bone-tempered & Shell-tempered & N \\
\hline Plain & 124 & 51 & 1 & 176 \\
Utility & 122 & 107 & - & 229 \\
Fine & 8 & 9 & - & 17 \\
\hline Totals & 254 & 167 & 1 & 422 \\
\hline
\end{tabular}


More than 93 percent of the decorated sherds from the Allan Howill site are from utility ware vessels (see Table 15), and the plain to decorated sherd ratio is 0.72 . The brushed to plain sherd ratio is 0.74 , and the ratio of brushed to other wet paste sherds is 1.30 . About 53 percent of the decorated sherds have brushing marks (Table 16), including rim sherds with diagonal, horizontal, or vertical brushed decorative elements.

Table 16. Decorative methods and elements represented in the utility ware and fine ware ceramics at the Allan Howill site (41SA24).

\begin{tabular}{llll}
\hline Ware & Rim & Body & $\mathrm{N}$ \\
\hline
\end{tabular}

Utility Ware

\section{Brushed}

diagonal brushed

horizontal brushed

opposed brushed

parallel brushed

vertical brushed

$\begin{array}{lll}2 & - & 2 \\ 3 & - & 3 \\ - & 6 & 6 \\ - & 118 & 118 \\ 1 & - & 1\end{array}$

\section{Incised}

curvilinear incised lines

$\begin{array}{lll}- & 2 & 2 \\ 1 & - & 1 \\ - & 3 & 3 \\ 1 & 1 & 2 \\ - & 1 & 1 \\ - & 32 & 32 \\ - & 17 & 17 \\ - & 1 & 1\end{array}$

diagonal incised lines

diagonal opposed incised lines

horizontal and opposed curvilinear incised lines

incised triangle el.

parallel incised lines

straight incised line

straight and curvilinear incised lines

2

1

3

2

1

32

17

1

\section{Incised-Punctated}

circular incised el. filled with tool punctates

curvilinear incised line and adjacent tool punctated zone

curvilinear incised panel filled with tool punctates

horizontal incised line and incised triangle el.

filled with tool punctates

incised triangle el. filled with tool punctates

straight incised line and adjacent tool punctated zone

\section{Pinched}

opposed pinched ridges

parallel pinched ridges

parallel and curvilinear pinched ridges

straight pinched ridge

$\begin{array}{lll}1 & - & 1 \\ - & 1 & 1 \\ - & 2 & 2 \\ - & 1 & 1\end{array}$

\section{Pinched-Incised}

straight pinched ridge and opposed parallel

$-$

- 1

6

6

incised lines 
Table 16. Decorative methods and elements represented in the utility ware and fine ware ceramics at the Allan Howill site (41SA24), cont.

\begin{tabular}{llll}
\hline Ware & Rim & Body & N \\
\hline $\begin{array}{l}\text { Punctated } \\
\text { circular punctated rows }\end{array}$ & - & 1 & 1 \\
fingernail punctated rows & - & 6 & 6 \\
tool punctated row & 3 & 9 & 12 \\
Ridged & & & 2 \\
parallel ridged & - & 2 &
\end{tabular}

Fine Ware

Engraved

cross-hatched engraved zone $\quad-\quad 11$

curvilinear engraved line $\quad-\quad 11$

curvilinear cross-hatched engraved zone $\quad-\quad 11$

diagonal engraved lines

horizontal and curvilinear engraved lines

with excised tick marks

horizontal and diagonal engraved lines

horizontal and diagonal scroll el.

horizontal and vertical engraved lines

parallel engraved lines

parallel engraved lines, and one line with

hatched triangle el.

rectilinear engraved el.

straight engraved line

$\begin{array}{lll}1 & 1 & 2\end{array}$

Totals

17

229

Other important utility wares at the site have incised ( 24.0 percent), punctated ( 7.7 percent), and incised-punctated (4.9 percent) decorative elements. The incised rim sherds have diagonal and horizontal-opposed curvilinear decorative elements (Figure 13a-b), and body sherds have geometric elements or curvilinear incised lines (see Table 16). Additional utility wares in the assemblage from the site have pinched (3.3 percent) decorative elements; these sherds are from Killough Pinched vessels. Two body sherds ( 0.8 percent) are from post-A.D. 1500 Belcher Ridged vessels. The incised-punctated sherds have circular, triangular, and panel incised elements filled with tool punctates (Figure 13c).

The most distinctive of the engraved sherds in the Allan Howill ceramic assemblage is a body sherd from a Patton Engraved, var. Fair (Perttula 2011:Figure 6-66d) vessel with horizontal and curvilinear engraved lines with small excised tick marks (Figure 14d). Rim sherds have diagonal or horizontal and vertical engraved lines, while another engraved rim from the site has large rectilinear panels (Figure 14a), and an additional rim has part of an engraved scroll element (Figure 14b). One of the body sherds has a curvilinear engraved zone filled with cross-hatched engraved lines (Figure 14c). 


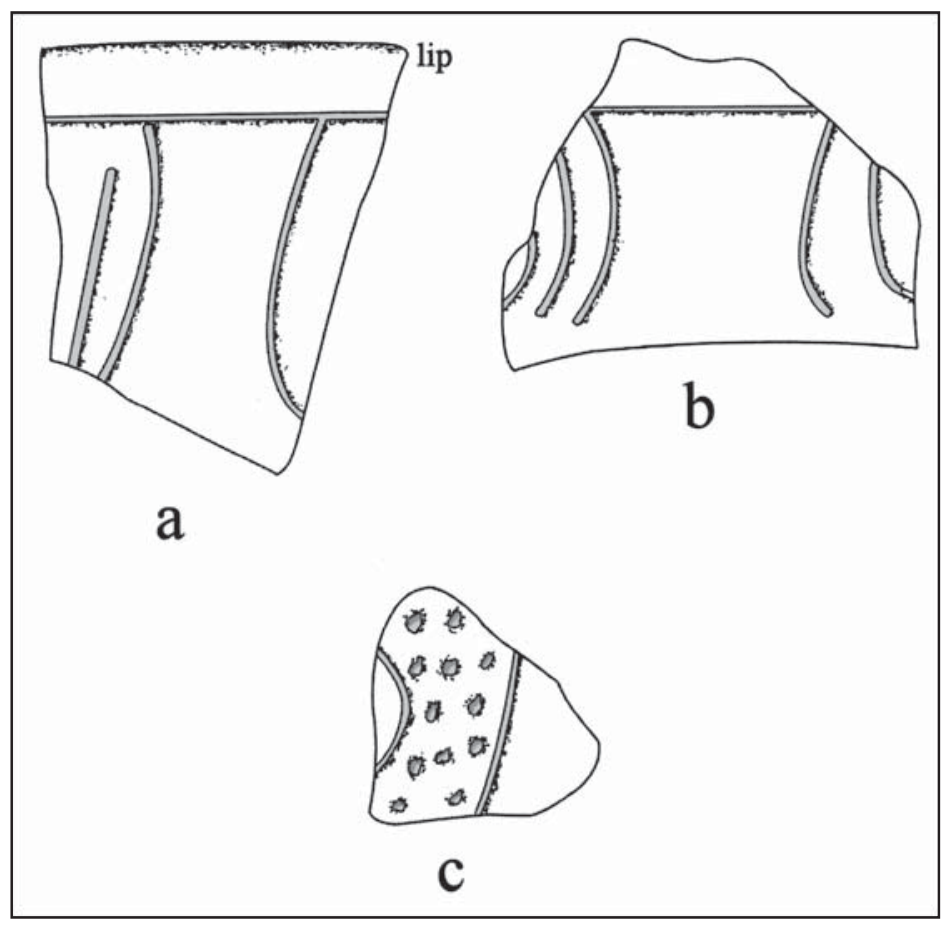

Figure 13. Selective decorative elements in utility ware sherds at the Allan Howill site (41SA24): a-b, incised; c, incised-punctated.

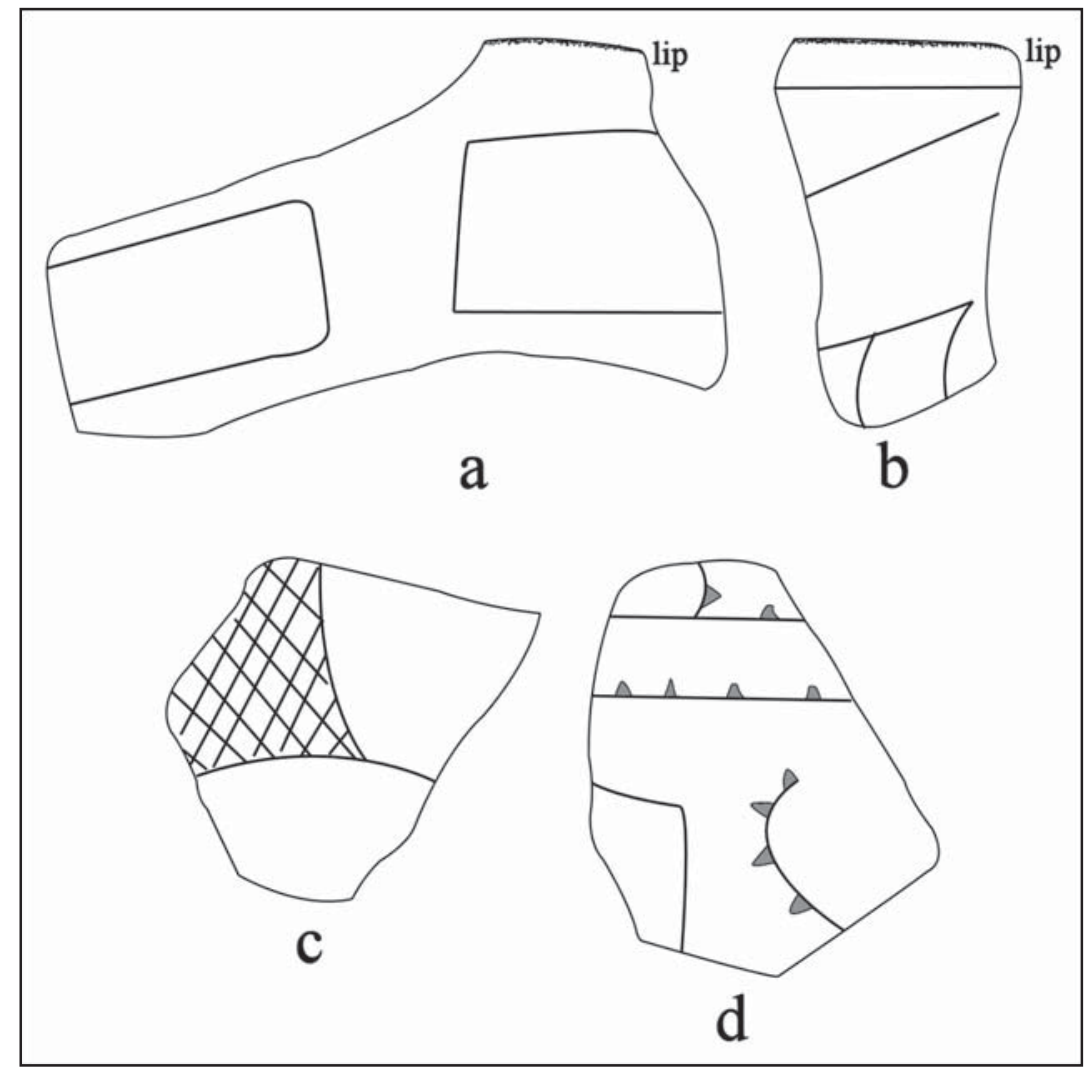

Figure 14. Selected decorative elements in engraved fine ware sherds at the Allan Howill site (41SA24). 


\section{H. C. Barton Site (41SA32)}

Both grog-tempered and bone-tempered ceramic vessels are represented in the 354 sherds in the H. C. Barton site assemblage (Table 17). Approximately 54 percent of the sherds are from grog-tempered vessels, and the highest proportion of grog-tempered sherds is in the utility wares (55.7 percent). Only 25 percent of the fine ware sherds are from grog-tempered vessels.

Table 17. Caddo ceramic wares at the H. C. Barton Site (41SA32).

\begin{tabular}{lccc}
\hline Ware & Grog-tempered & Bone-tempered & N \\
\hline Plain & 107 & 90 & 197 \\
Utility & 83 & 66 & 149 \\
Fine & 2 & 6 & 8 \\
\hline Totals & 192 & 162 & 354 \\
\hline
\end{tabular}

The plain to decorated sherd ratio of the assemblage is 1.25 . About 95 percent of the decorated sherds are from utility ware vessels, particularly rim and body sherds with brushed and brushed-incised decorative elements: these sherds account for 74.5 percent of the decorated sherds from the H. C. Barton site (Table 18). The brushed to plain sherd ratio in this assemblage is 0.59 , and the ratio of brushed to other wet paste sherds is 3.16. Three of the brushed-incised sherds may be from Spradley BrushedIncised vessels, as these have brushed decorations that are overlain by sets of incised lines with various orientations; Spradley Brushed-Incised sherds are typically found in Historic Caddo Allen phase sites in East Texas (see Perttula and Selden 2014).

Table 18. Decorative methods and elements represented in the utility ware and fine ware ceramics at the H. C. Barton site (41SA32).

\begin{tabular}{llll}
\hline Ware & Rim & Body & $\mathrm{N}$ \\
\hline
\end{tabular}

\section{Utility Ware}

Brushed

horizontal brushed

opposed brushed

parallel brushed

vertical brushed

$\begin{array}{lll}3 & - & 3 \\ - & 2 & 2 \\ - & 105 & 105 \\ 2 & - & 2\end{array}$

Brushed-Incised

incised panel filled with parallel brushing marks parallel brushed and overlying diagonal incised lines parallel brushed and overlying opposed incised lines parallel brushed and overlying parallel incised lines

\section{Incised}

diagonal incised lines

diagonal opposed incised lines

diagonal-vertical incised lines

parallel incised lines

straight incised line

$\begin{array}{lll}1 & 1 \\ - & 1 & 1 \\ - & 1 & 1 \\ 2 & 2 \\ 3 & & \\ - & - & 3 \\ - & 1 & 1 \\ 1 & 1 \\ 14 & 14 \\ 8 & 8\end{array}$


Table 18. Decorative methods and elements represented in the utility ware and fine ware ceramics at the H. C. Barton site (41SA32), cont.

\begin{tabular}{llll}
\hline Ware & Rim & Body & N \\
\hline $\begin{array}{l}\text { Ridged } \\
\text { parallel ridged }\end{array}$ & - & 5 & 5
\end{tabular}

\section{Fine Ware}

\section{Engraved}

cross-hatched engraved zone and straight

engraved line

engraved brackets

engraved bracket and rectilinear el.

hatched engraved zone

horizontal engraved line

horizontal engraved line with excised tick marks

horizontal and diagonal opposed engraved lines

\begin{tabular}{cccc} 
& - & 1 & 1 \\
& - & 1 & 1 \\
1 & - & 1 \\
& - & 1 & 1 \\
1 & - & 1 \\
1 & - & 1 \\
& - & 1 & 1 \\
\hline & & & 157 \\
\hline & 1 & - & 145 \\
\hline
\end{tabular}

\section{Slipped}

int./ext. red-slipped

12

The incised sherds comprise 17.2 percent of the decorated sherds, and these have Maydelle Incised decorative elements (see Table 18); the rims have diagonal incised lines. Another 3.2 percent of the sherds from the H. C. Barton site are body sherds from post-A.D. 1500 Belcher Ridged vessels.

The fine ware sherds from the H. C. Barton site include a bowl rim sherd with an ochre-rich red slip on both interior and exterior vessel surfaces (see Table 18) and seven engraved sherds; these fine wares comprise only 4.5 percent of the decorated sherds from the site. The most distinctive of the engraved sherds is a Patton Engraved, var. unspecified rim with excised tick marks on a horizontal engraved line below the lip (Figure 15a), sherds with cross-hatched (Figure $15 \mathrm{~b})$ and hatched zones, and two sherds with engraved open bracket elements (Figure 15c-d).

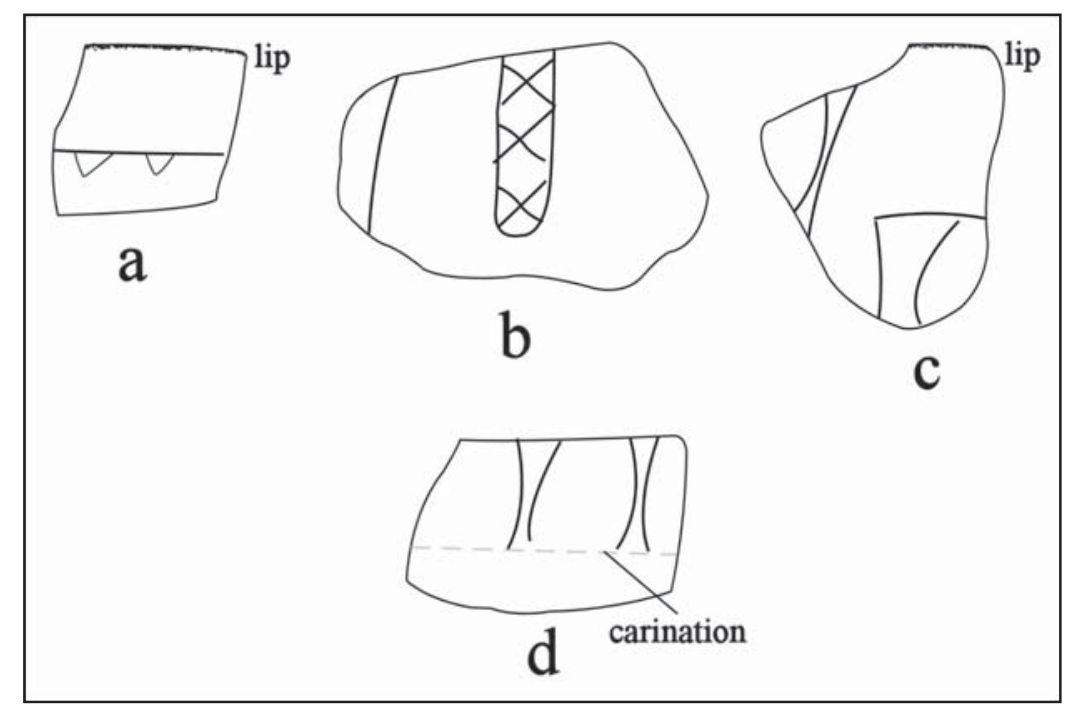

Figure 15. Selected decorative elements in engraved sherds from the H. C. Barton site (41SA32). 


\section{Sam Williams Site (41SA77)}

A total of 343 ancestral Caddo ceramic sherds are in the TARL collections from the Sam Williams site (Table 19). More than 97 percent of the sherds are from grog-tempered vessels.

Table 19. Caddo ceramic wares at the Sam Williams site (41SA77).

\begin{tabular}{lccc}
\hline Ware & Grog-tempered & Bone-tempered & N \\
\hline Plain & 242 & 8 & 250 \\
Utility & 78 & 1 & 79 \\
Fine & 14 & - & 14 \\
\hline Totals & 334 & 9 & 343 \\
\hline
\end{tabular}

The plain to decorated sherd ratio of the assemblage is 2.69 , and 85 percent of the decorated sherds are from utility ware vessels. Most of these sherds are from vessels with incised decorative elements (Table 20), as they comprise 40 percent of the decorated sherds from the Sam Williams site; rims have diagonal and horizontal incised lines. Sherds with punctated decorative elements account for another 30 percent of the decorated sherd assemblage, particularly with decorative elements featuring rows of either fingernail or tool punctations.

Table 20. Decorative methods and elements represented in the utility ware and fine ware ceramics at the Sam Williams site (41SA77).

\begin{tabular}{lllll}
\hline Ware & Rim & Body & $\mathrm{N}$ \\
\hline
\end{tabular}

\section{Utility Ware}

\section{Brushed}

parallel brushed

\section{Incised}

curvilinear incised line

diagonal incised lines

diagonal opposed incised lines

horizontal incised lines

parallel incised lines

straight incised line

vertical incised lines

vertical and diagonal incised lines
$-$

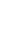

\section{Incised-Punctated}

circular incised zones filled with tool punctates curvilinear incised zones filled with circular punctates curvilinear incised zone filled with tool punctates diagonal incised line and adjacent tool punctated zone parallel incised lines and adjacent tool punctated zone straight incised line and adjacent tool punctated zone

$\begin{array}{lll}- & 2 & 2 \\ 2 & - & 2 \\ - & 4 & 4 \\ 2 & 1 & 3 \\ - & 17 & 17 \\ - & 7 & 7 \\ - & 1 & 1 \\ 1 & - & 1\end{array}$


Table 20. Decorative methods and elements represented in the utility ware and fine ware ceramics at the Sam Williams site (41SA77), cont.

\begin{tabular}{llll}
\hline Ware & Rim & Body & N \\
\hline Punctated & & & 3 \\
circular punctated rows & - & 3 & 8 \\
fingernail punctated rows & - & 8 & 1 \\
fingernail punctate, single & - & 1 & 16 \\
tool punctated rows & - & 16 &
\end{tabular}

\section{Fine Ware}

\section{Engraved}

cross-hatched engraved zone curvilinear hatched zone curvilinear engraved lines diagonal engraved lines diagonal opposed engraved lines hatched engraved zones horizontal engraved lines horizontal and diagonal engraved lines horizontal-diagonal engraved lines and bracket el.

straight engraved line

$\begin{array}{lll}- & 1 & 1 \\ - & 1 & 1 \\ - & 1 & 1 \\ 1 & - & 1 \\ - & 1 & 1 \\ - & 3 & 3 \\ 2 & - & 2 \\ 1 & - & 1 \\ - & 1 & 1 \\ - & & 2\end{array}$

Totals

9

84

Sherds with incised-punctated decorative elements comprise 10.8 percent of the decorated sherds (see Table 20). These have circular and curvilinear incised panels filled with punctations (Figure 16a-c). Sherds with brushing marks only account for 4.3 percent of the decorated sherds from the Sam Williams site.

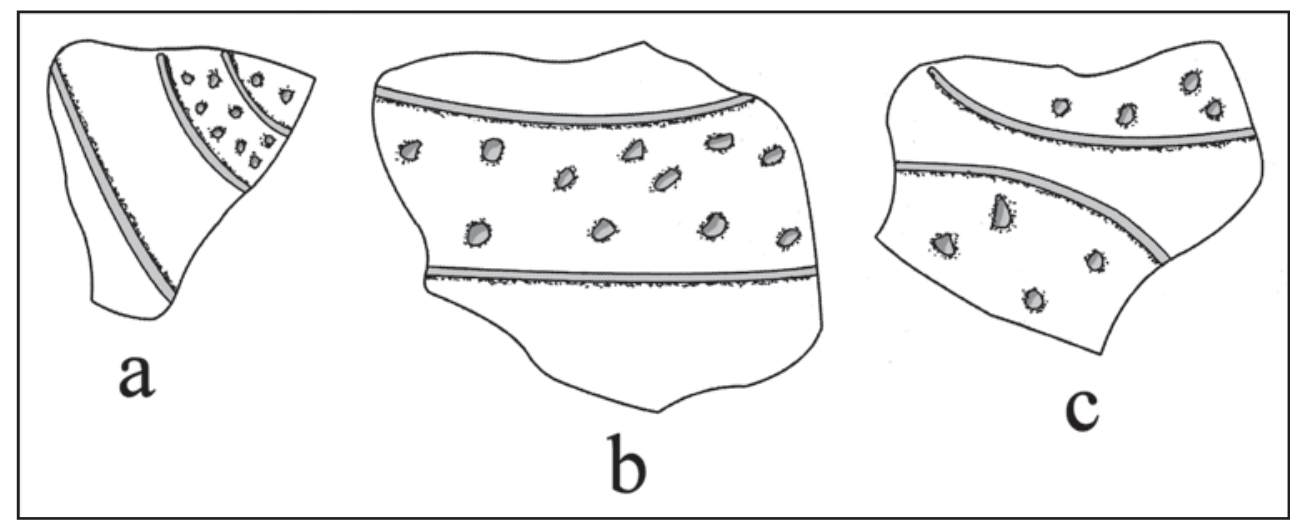

Figure 16. Selected decorative elements on incised-punctated body sherds from the Sam Williams site. 
Engraved rim sherds in the Sam Williams site ceramic assemblage have diagonal, horizontal, and horizontal-diagonal engraved elements (see Table 20). A number of the body sherds have cross-hatched or hatched zones (Figure 17a-c).

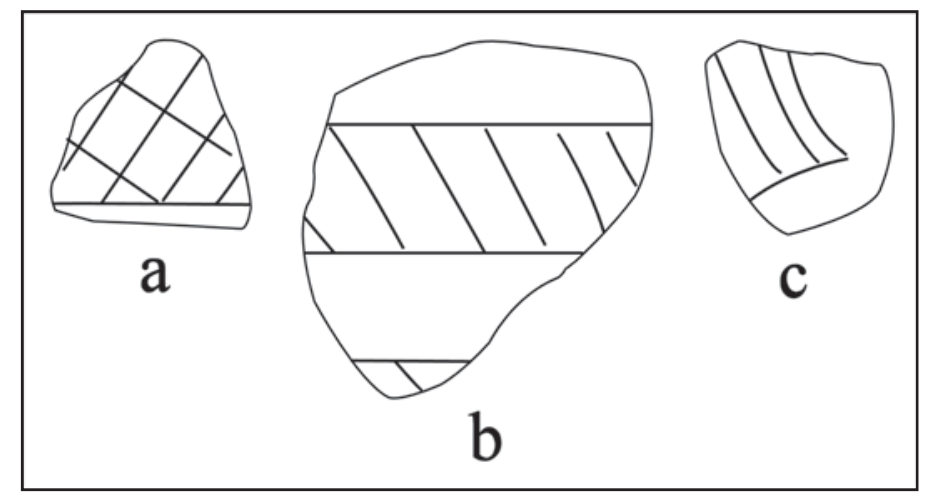

Figure 17. Selected decorative elements on engraved fine ware body sherds from the Sam Williams site.

\section{Hanks Site (41SA80)}

The ceramic wares from the Hanks site are from vessels tempered with grog (53 percent), bone (46.4 percent), and shell ( 0.4 percent) (Table 21$)$; the highest proportion of grog-tempered sherds are in the plain ware (57 percent), while the highest proportion of bone-tempered sherds are in the utility ware (53.4 percent). The one shell-tempered body sherd in the assemblage is decorated with parallel incised lines, and may be from the body of an Emory Punctated-Incised vessel of post-A.D. 1680 age.

Table 21. Caddo ceramic wares at the Hanks site (41SA80).

\begin{tabular}{lcccc}
\hline Ware & Grog-tempered & Bone-tempered & Shell-tempered & N \\
\hline Plain & 84 & 63 & - & 147 \\
Utility & 40 & 47 & $1 *$ & 88 \\
Fine & 11 & 8 & - & 19 \\
\hline Totals & 135 & 118 & 1 & 254 \\
\hline
\end{tabular}

*parallel incised lines on a body sherd

The plain to decorated sherd ratio in the Hanks site assemblage is 1.37. About 82 percent of the decorated sherds are from utility wares, primarily sherds from incised (36 percent) and brushed/brushedincised (34 percent) vessels (Table 22). The brushed to plain sherd ratio is 0.24 and the brushed to other wet paste sherds ratio is 0.68 . 
Table 22. Decorative methods and elements represented in the utility ware and fine ware ceramics at the Hanks site (41SA80).

\begin{tabular}{llll}
\hline Ware & Rim & Body & $\mathrm{N}$ \\
\hline
\end{tabular}

\section{Utility Ware}

\section{Appliqued}

circular appliqued node

\section{Appliqued-Incised}

circular incised lines around a circular

appliqued node

\section{Brushed}

diagonal brushed

parallel brushed

\section{Brushed-Incised}

parallel brushed-incised marks and lines

\section{Incised}

cross-hatched incised lines

cross-hatched semi-circular incised zones curvilinear incised line

diagonal incised lines

diagonal opposed incised lines

horizontal and diagonal incised lines

horizontal-diagonal incised lines (rim) and

$\begin{array}{lll}- & 3 & 3 \\ - & 1 & 1 \\ - & 2 & 2 \\ 1 & 1 & 2 \\ - & 1 & 1 \\ - & 2 & 2 \\ - & 1 & 1\end{array}$

vertical incised lines (body)

horizontal-vertical incised lines

parallel incised lines

parallel incised lines, closely-spaced

straight incised line

3

1

2

2

1

2

1

1

17

3

6

\section{Incised-Punctated}

curvilinear incised lines and adjacent tool

punctated row

straight incised line and adjacent fingernail punctated row

straight incised line and adjacent linear punctated row

vertical incised panels filled with tool punctations 
Table 22. Decorative methods and elements represented in the utility ware and fine ware ceramics at the Hanks site (41SA80), cont.

\begin{tabular}{l} 
Ware \\
\hline Punctated \\
cane punctated rows \\
circular punctated rows \\
fingernail punctated rows \\
tool punctated rows
\end{tabular}

Rim Body

\section{Ridged}

parallel ridged

$\begin{array}{lll}- & 1 & 1 \\ - & 1 & 1 \\ - & 1 & 1 \\ 1 & 1 & 2\end{array}$

\section{Fine Ware}

\section{Engraved}

curvilinear and straight engraved lines curvilinear and diagonal engraved lines curvilinear and parallel engraved lines diagonal engraved lines hatched engraved zone horizontal and curvilinear engraved lines horizontal and vertical engraved lines with excised triangular tick marks parallel engraved lines parallel engraved lines with excised tick marks parallel engraved lines, one with excised tick marks

straight engraved line

$\begin{array}{lll}- & 1 & 1 \\ - & 1 & 1 \\ - & 1 & 1 \\ 1 & - & 1 \\ - & 1 & 1 \\ - & 1 & 1 \\ 1 & - & 1 \\ - & 4 & 4 \\ - & 1 & 1 \\ - & 3 & 3 \\ - & 1 & 1\end{array}$

\section{Trailed}

parallel trailed lines

Sherds with appliqued decorative elements are a distinctive part of the Hanks site decorated sherd assemblage; appliqued sherds account for 2.8 percent of the decorated sherd assemblage (see Table 22). These have either a large circular appliqued node, or large circular appliqued nodes in a circular incised zone (Figure 18a-b). The incised sherds in the assemblage have cross-hatched lines, cross-hatched semicircular incised zones (Figure 18f), a curvilinear incised line, diagonal incised lines, diagonal opposed incised lines, horizontal and diagonal incised lines (Figure 18c), horizontal-diagonal incised lines on the rim and vertical incised lines on the vessel body (Figure 18d), and horizontal-vertical incised lines (Figure 18f). 


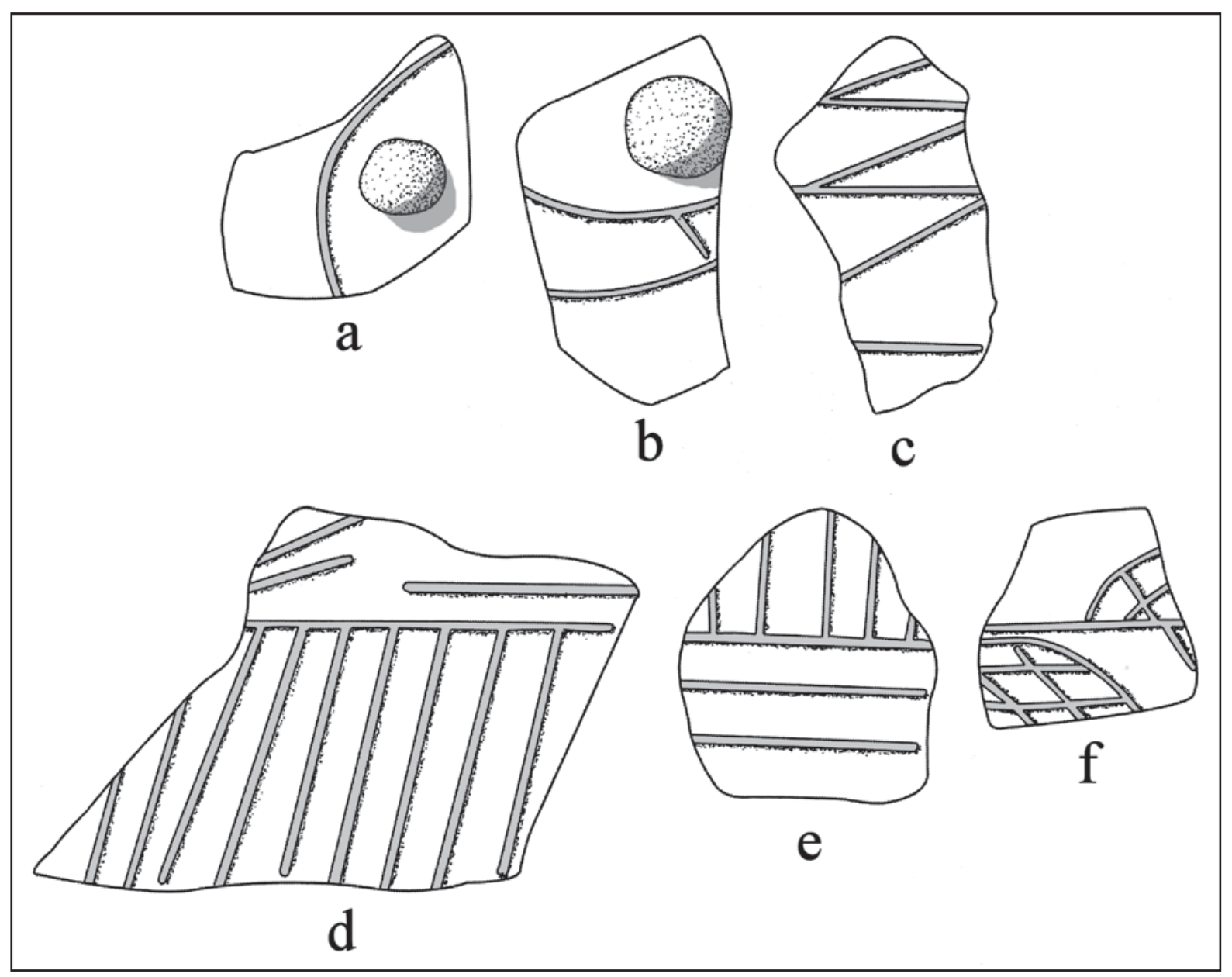

Figure 18. Selected decorative elements in the utility ware sherds from the Hanks site (41SA80): a-b, appliqued-incised; c-f, incised.

Incised-punctated sherds represent only 3.7 percent of the decorated sherds from the Hanks site (see Table 22). These sherds have incised zones or panels filled with punctations (see Figure 18g). Sherds with punctated elements - rows of punctations of different shapes - comprise 4.7 percent of the decorated sherd assemblage, and one sherd is from a post-A.D. 1500 Belcher Ridged vessel (see Table 22).

The fine wares at the Hanks site are from engraved (15 percent) and trailed ( 2.8 percent) vessels; the trailed sherds may be from a Keno Trailed vessel. One engraved rim sherd (Figure 19a) and four body sherds (Figure 19d-g) are from Patton Engraved vessels with excised tick marks pendant from straight or horizontal engraved lines. One engraved body sherd has a narrow hatched zone (Figure 19b), and another engraved sherd is from a Taylor Engraved vessel with a series of curvilinear engraved lines (Figure 19c). 


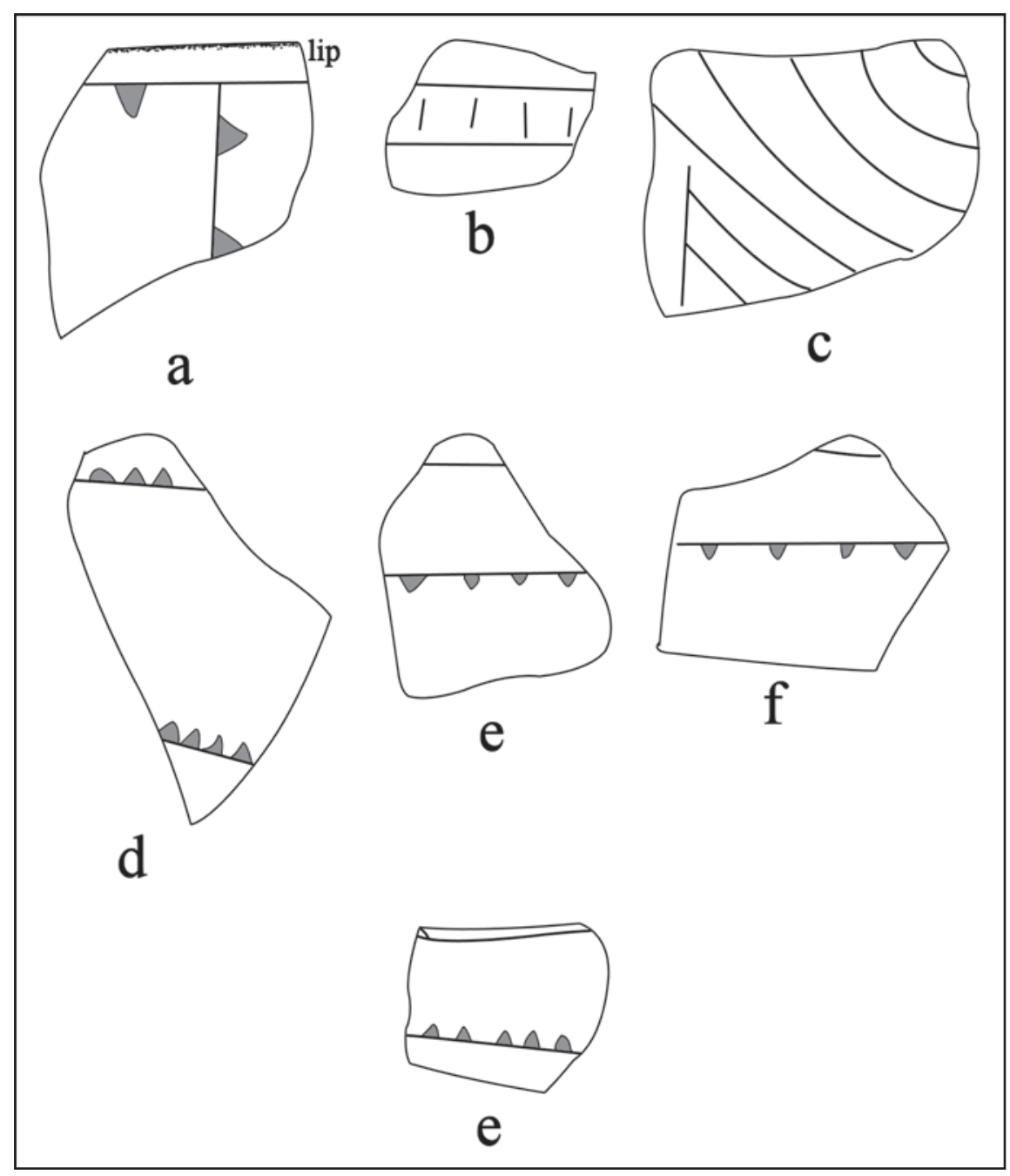

Figure 19. Selected decorative elements in the engraved fine ware sherds from the Hanks site (41SA80).

\section{John McGilberry Site (41SA85)}

The ancestral Caddo ceramic wares from the John McGilberry site are primarily (74 percent) from grog-tempered vessels; the remaining 26 percent of the sherds are from bone-tempered vessels (Table $23)$. Of the decorated sherds in the assemblage, 85.3 percent are from utility ware vessels.

Table 23. Caddo ceramic wares at the John McGilberry site (41SA85).

\begin{tabular}{lccc}
\hline Ware & Grog-tempered & Bone-tempered & N \\
\hline Plain & 129 & 45 & 174 \\
Utility & 94 & 34 & 128 \\
Fine & 17 & 5 & 22 \\
\hline Totals & 240 & 84 & 324 \\
\hline
\end{tabular}


The plain to decorated sherd ratio in this assemblage is 1.16 . About 57 percent of the sherds have brushed marks, either as the sole decorative element or in combination with brushed-appliqued (Pease Brushed-Incised), brushed-punctated, and brushed-punctated-appliqued decorative elements (Table 24). The brushed to plain sherd ratio is 0.51 , and the brushed to other wet paste sherds ratio is 1.87 .

Table 24. Decorative methods and elements represented in the utility ware and fine ware ceramics at the John McGilberry site (41SA85).

\begin{tabular}{llll}
\hline Ware & Rim & Body & $\mathrm{N}$ \\
\hline
\end{tabular}

Utility Ware

Appliqued-Incised

straight appliqued filler and parallel incised lines

1

Brushed

horizontal brushed

opposed brushed

overlapping brushed

parallel brushed

2

$-$

$-$

$-$

Brushed-Appliqued

parallel brushed and straight appliqued fillet

Brushed-Punctated

horizontal brushed with tool punctated row

beneath the lip

parallel brushed and tool punctated row

through the brushing

\section{Brushed-Punctated-Appliqued}

parallel brushed, parallel appliqued fillet, and parallel tool punctated rows through the brushing

parallel brushed, straight appliqued ridge, and diagonal

tool punctated rows through the brushing

\section{Incised}

cross-hatched incised lines

diagonal opposed incised lines

horizontal and diagonal incised lines

parallel incised lines

straight incised line

vertical incised lines

Incised-Pinched

horizontal incised lines above horizontal pinched ridge

2

1

1

77

2

1

1

2

1

2

1

5

3

1 
Table 24. Decorative methods and elements represented in the utility ware and fine ware ceramics at the John McGilberry site (41SA85), cont.

\begin{tabular}{|c|c|c|c|}
\hline Ware & $\operatorname{Rim}$ & Body & $\mathrm{N}$ \\
\hline \multicolumn{4}{|l|}{ Incised-Punctated } \\
\hline $\begin{array}{l}\text { curvilinear incised zone with tool punctations } \\
\text { and curvilinear incised lines }\end{array}$ & 1 & - & 1 \\
\hline diagonal incised panels filled with circular punctates & - & 1 & 1 \\
\hline $\begin{array}{l}\text { horizontal incised lines and crescent-shaped } \\
\text { fingernail punctations }\end{array}$ & 1 & - & 1 \\
\hline incised triangle el. filled with circular punctates & - & 1 & 1 \\
\hline incised triangle el. filled with tool punctates & 2 & - & 2 \\
\hline straight incised line and adjacent circular punctated zone & - & 2 & 2 \\
\hline straight incised line and adjacent tool punctated zone & - & 5 & 5 \\
\hline \multicolumn{4}{|l|}{ Pinched } \\
\hline parallel pinched ridges & - & 1 & 1 \\
\hline \multicolumn{4}{|l|}{ Punctated } \\
\hline cane punctated rows & - & 1 & 1 \\
\hline circular punctated rows & - & 1 & 1 \\
\hline fingernail punctated rows & - & 3 & 3 \\
\hline linear tool punctated row & - & 1 & 1 \\
\hline tool punctated row beneath the lip & 1 & - & 1 \\
\hline tool punctated rows & - & 4 & 4 \\
\hline
\end{tabular}

\section{Fine Ware}

\section{Engraved}

closely-spaced curvilinear engraved lines curvilinear engraved line

closely-spaced curvilinear engraved lines and pendant semi-circle with excised dot curvilinear cross-hatched engraved zone diagonal engraved lines

diagonal panels filled with curvilinear and diagonal hatched lines diagonal opposed engraved lines horizontal and curvilinear engraved lines horizontal and closely-spaced curvilinear engraved lines; hooked arm el.

horizontal-diagonal engraved lines opposed engraved lines parallel engraved lines straight engraved line triangle engraved el.

$\begin{array}{lll}- & 3 & 3 \\ - & 1 & 1 \\ - & 1 & 1 \\ - & 1 & 1 \\ 1 & - & 1 \\ - & 1 & 1 \\ - & 1 & 1 \\ - & 1 & 1 \\ - & 1 & 1 \\ & & \\ 1 & 2 & 3 \\ - & 1 & 1 \\ - & 2 & 2 \\ - & 4 & 1 \\ - & 1 & 150\end{array}$

Totals 
Other utility wares in the John McGilberry site assemblage include sherds from incised (8.7 percent), incised-punctated (8.7 percent) (Figure 20), punctated ( 7.3 percent), Killough Pinched (1.3 percent), incised-pinched ( 0.7 percent), and appliqued-incised ( 0.7 percent) vessels (see Table 24$)$. The incised sherds have simple geometric elements (see Table 24), while the incised-punctated rim and body sherds from the site have incised triangle, diagonal panels, and curvilinear zones filled with circular or tool punctates (Figure 20b-d). One incised-punctated rim sherd is from a Weches Fingernail Impressed, var. Weches vessel (Figure 20a, see Stokes and Woodring 1981:Figure 22n-p), indicating use of the site sometime prior to ca. A.D. 1200. The punctated sherds have rows of cane, circular, fingernail, or tool punctates on vessel rim and body surfaces (see Table 24).

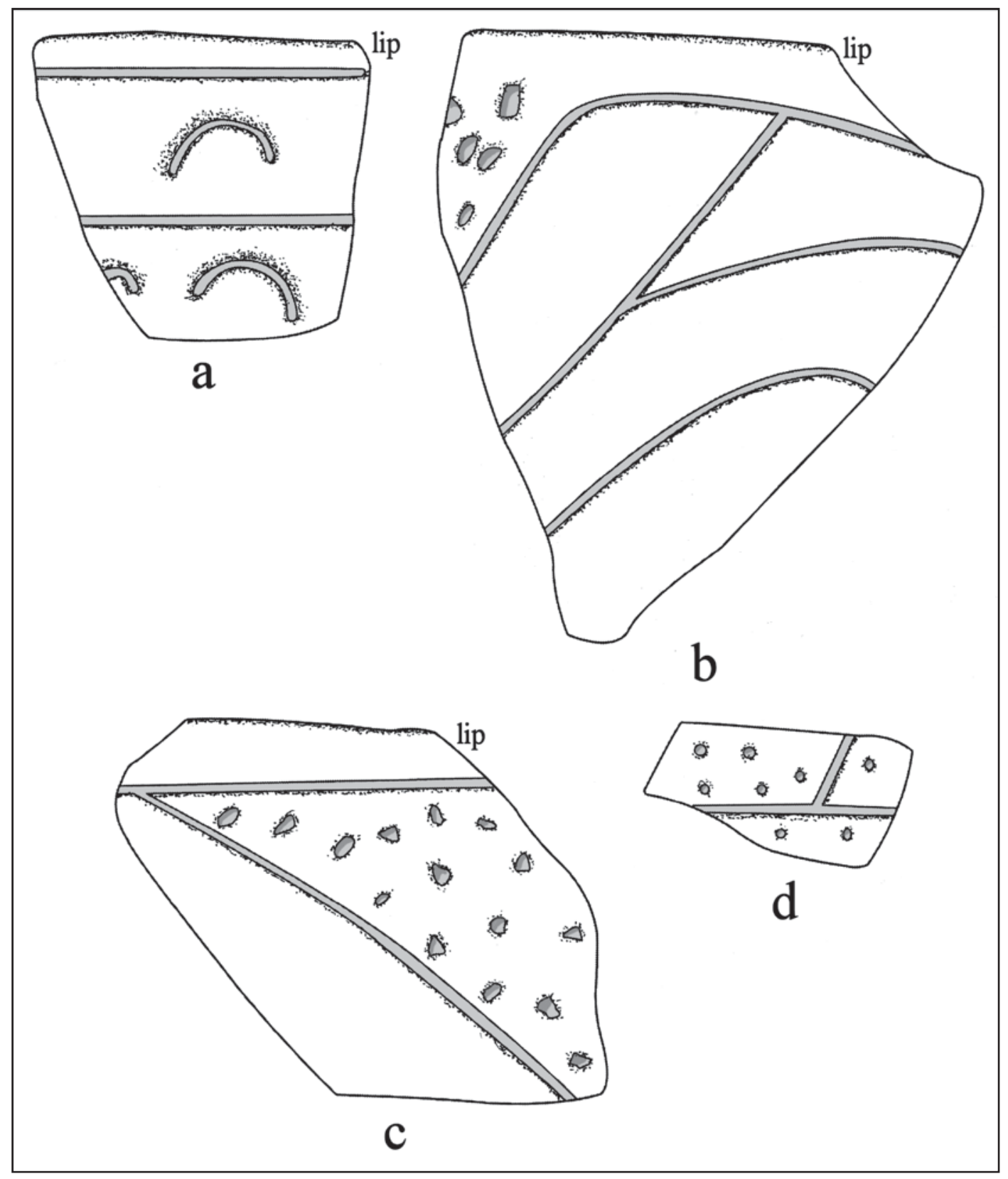

Figure 20. Selected decorative elements in incised-punctated rim and body sherds from the John McGilberry site (41SA85). 
The engraved sherds from the site have several examples that may be from Poynor Engraved vessels (Figure 21a-b), as they have closely-spaced sets of curvilinear or horizontal engraved lines; one set on one sherd ends in a hooked arm element. The rim sherds in the assemblage have diagonal or horizontaldiagonal engraved lines, and several body sherds have the same elements (Figure 21e-f). A body sherd has diagonal panels filled with curvilinear and diagonal hatched lines (Figure 21c), and another distinctive body sherd has closely-spaced curvilinear engraved lines and a pendant semi-circle with a central excised dot (Figure 21d).

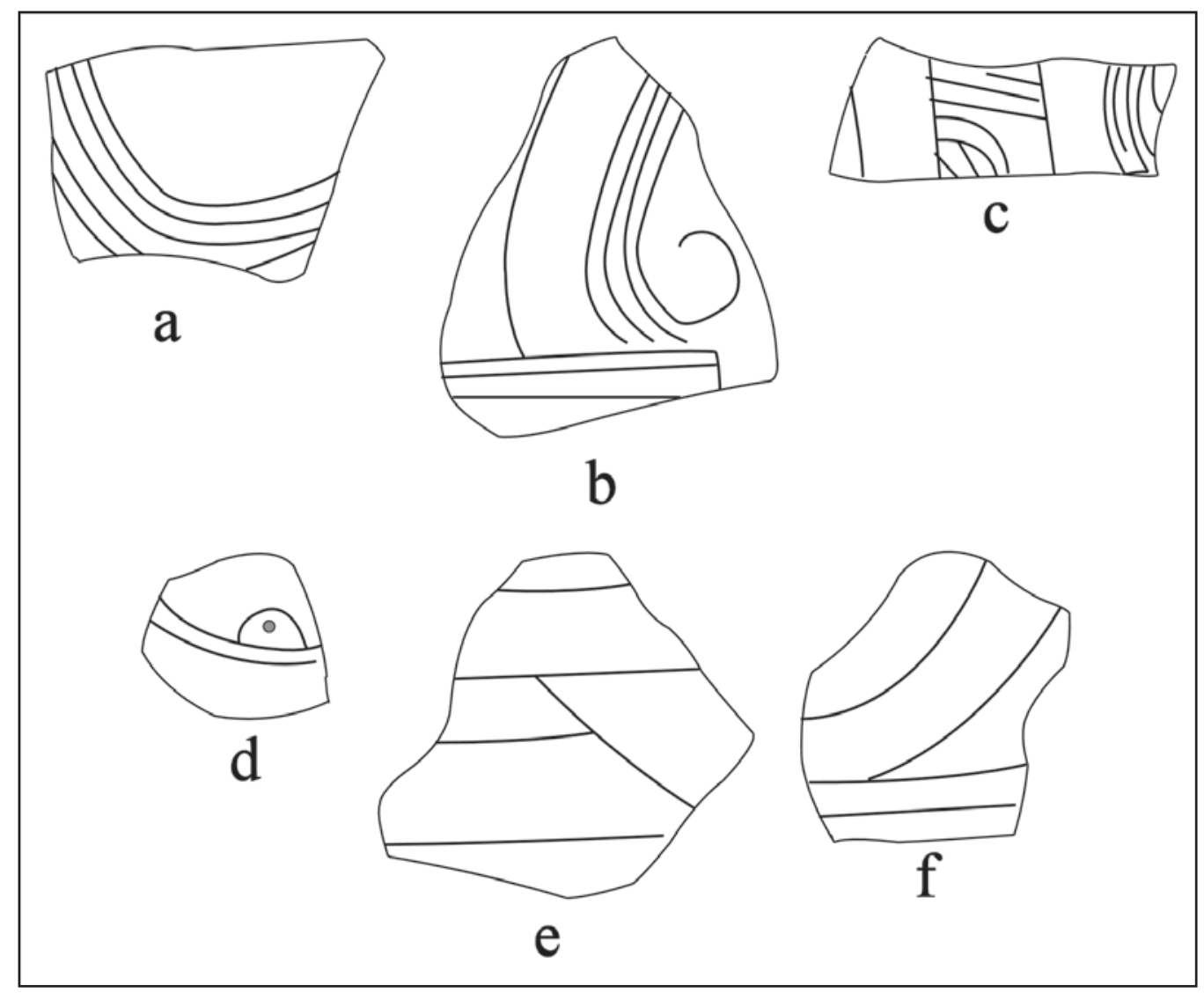

Figure 21. Selected engraved fine ware decorative elements on body sherds from the John McGilberry site.

\section{C. Hines Site (41SA95)}

The large ancestral Caddo ceramic vessel sherd assemblage $(n=771)$ from the D. C. Hines site is primarily from grog-tempered vessels (92.6 percent); the highest proportion of sherds from bonetempered vessels occurs in the fine wares (9.4 percent (Table 25). Of the 359 decorated sherds in the assemblage, approximately 91 percent are from utility wares, particularly sherds from incised (43.2 percent) and punctated (30.4 percent) vessels (Table 26). 
Table 25. Caddo ceramic wares at the D. C. Hines site (41SA95).

\begin{tabular}{lccc}
\hline Ware & Grog-tempered & Bone-tempered & N \\
\hline Plain & 386 & 26 & 412 \\
Utility & 299 & 28 & 327 \\
Fine & 29 & 3 & 32 \\
\hline Totals & 714 & 57 & 771 \\
\hline
\end{tabular}

Table 26. Decorative methods and elements represented in the utility ware and fine ware ceramics at the D. C. Hines site (41SA95).

\begin{tabular}{llll}
\hline Ware & Rim & Body & $\mathrm{N}$ \\
\hline
\end{tabular}

Utility Ware

\section{Brushed}

diagonal brushed

horizontal brushed

parallel brushed

1

3

$-$

\section{Brushed-Incised}

horizontal brushed and overlying incised triangle el.

parallel brushed and overlying diagonal incised lines

Incised

cross-hatched incised lines

curvilinear incised line

diagonal incised lines

diagonal opposed incised lines

horizontal incised lines

horizontal and diagonal incised lines

horizontal and diagonal opposed incised lines

opposed incised lines

parallel incised lines

straight incised line

vertical incised lines

vertical and diagonal opposed incised lines
1

1

1

2

9

18

14

9

2

3

72

21

1

3

Incised-Punctated

horizontal incised panel with crescent-shaped fingernail punctates

opposed incised lines and adjacent linear tool punctated row parallel incised lines and adjacent tool punctated zone straight incised line and adjacent fingernail punctated zone straight incised line and adjacent tool punctated zone incised triangle el. filled with tool punctates and adjacent row of tool punctates 
Table 26. Decorative methods and elements represented in the utility ware and fine ware ceramics at the D. C. Hines site (41SA95), cont.

\begin{tabular}{llll}
\hline Ware & Rim & Body & $\mathrm{N}$ \\
\hline
\end{tabular}

Utility Ware, cont.

\section{Punctated}

circular punctated rows

single fingernail punctate

fingernail punctated rows

tool punctated rows

$\begin{array}{lll}1 & - & 1 \\ - & 1 & 1 \\ 1 & 82 & 83 \\ 1 & 23 & 24\end{array}$

\section{Fine Ware}

\section{Engraved}

closely-spaced curvilinear engraved lines $\quad-\quad 115$

cross-hatched engraved zone

curvilinear engraved line

diagonal engraved lines

diagonal opposed engraved lines

narrow hatched zone

horizontal engraved lines

horizontal and diagonal engraved lines

parallel engraved lines

straight engraved line

vertical and horizontal engraved lines

Totals

44

\begin{tabular}{lll}
- & 5 & 5 \\
- & 1 & 1 \\
- & 1 & 1 \\
- & 1 & 1 \\
- & 4 & 4 \\
3 & - & 3 \\
- & 1 & 1 \\
- & 11 & 11 \\
- & 5 & 5 \\
1 & - & 1 \\
\hline 44 & 315 & 359 \\
\hline
\end{tabular}

The plain to decorated sherd ratio in the assemblage is 1.15. Brushed and brushed-incised (Figure 22a) sherds account for 13.4 percent of the decorated sherds (see Table 26), and the brushed to plain sherd ratio is only 0.12 . The brushed to other wet paste sherds ratio is 0.17 .

More than 70 percent of the rim sherds in the assemblage have incised decorative elements. These include rims with diagonal incised $(n=9)$, diagonal opposed $(n=3)$, horizontal $(n=14)$ lines, horizontal and diagonal lines $(n=4)$, horizontal and diagonal opposed lines $(n=2)$, and vertical incised lines $(n=1)$ (see Figure 22b-f). Incised-punctated sherds have incised panels and triangle elements filled with fingernail or tool punctations (see Figure 22g).

The punctated sherds in the D. C. Hines site ceramic assemblage are distinctive because of not only their abundance, but by the considerable proportion of sherds from fingernail punctated vessels. Fingernail punctated sherds comprise 78 percent of the punctated sherds in this site collection (see Table 26).

The fine ware rim sherds have horizontal engraved lines or horizontal and vertical engraved lines (see Table 26). Body sherds have sets of curvilinear engraved lines, hatched or cross-hatched engraved zones, or diagonal and diagonal opposed engraved lines. 


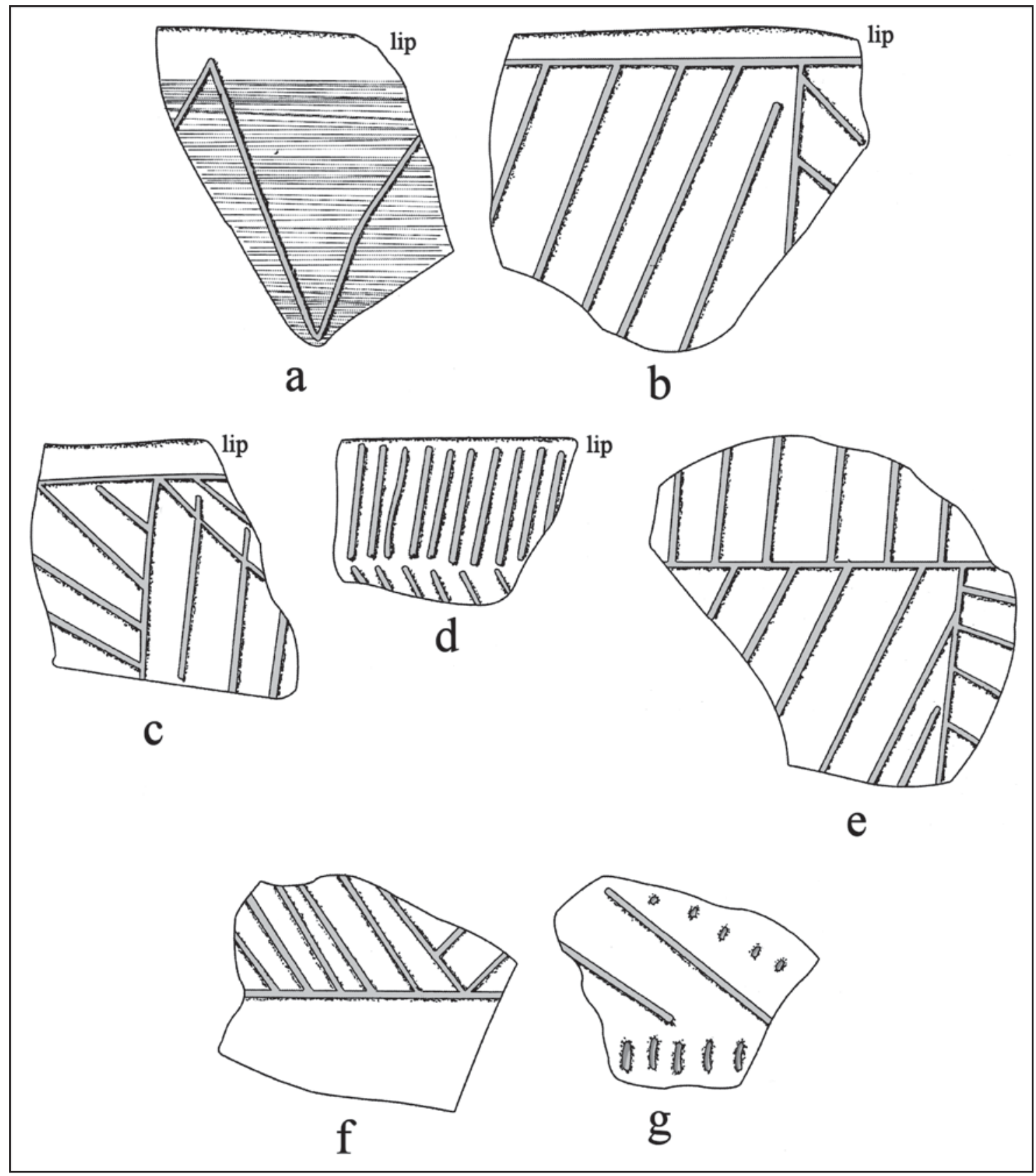

Figure 22. Selected decorative elements in utility ware sherds from the D. C. Hines site: a, brushed-incised; b-f, incised; g, incised-punctated.

\section{Childress Site (41SA96)}

The ancestral Caddo ceramic wares at the Childress site are tempered with grog (72 percent) and bone (28 percent (Table 27); the highest proportion of bone temper is noted in the fine wares (40 percent). The 100 decorated sherds in the assemblage are from both utility ware (90 percent) and fine ware (10 percent) vessels. 
Table 27. Caddo ceramic wares at the Childress site (41SA96).

\begin{tabular}{lccc}
\hline Ware & Grog-tempered & Bone-tempered & N \\
\hline Plain & 118 & 39 & 157 \\
Utility & 61 & 29 & 90 \\
Fine & 6 & 4 & 10 \\
\hline Totals & 185 & 72 & 257 \\
\hline
\end{tabular}

The plain to decorated sherd ratio of the assemblage is 1.57 . Forty percent of the decorated sherds have brushing marks (Table 28), including several rims with horizontal brushing, and the brushed to plain sherd ratio is 0.25 . The brushed to other wet paste sherds ratio is 0.8 .

Table 28. Decorative methods and elements represented in the utility ware and fine ware ceramics at the Childress site (41SA96).

Ware $\quad$ Rim $\quad$ Body $\quad N$

\section{Utility Ware}

\section{Brushed}

horizontal brushed

opposed brushed

parallel brushed

$\begin{array}{lll}4 & - & 4 \\ - & 1 & 1 \\ - & 35 & 35\end{array}$

\section{Incised}

curvilinear incised lines

diagonal opposed incised lines

horizontal incised line

horizontal-diagonal incised lines

opposed incised lines

parallel incised lines

straight incised line

vertical incised lines

\section{Incised-Punctated}

small incised circle filled with tool punctates, and adjacent tool punctated row

circular incised zone filled with fingernail punctates circular incised zone filled with tool punctates incised triangle el. filled with tool punctates straight incised line and adjacent tool punctated zone

$\begin{array}{lll}- & 1 & 1 \\ - & 1 & 1 \\ 1 & - & 1 \\ 1 & - & 1 \\ - & 2 & 2 \\ - & 15 & 15 \\ - & 6 & 6 \\ 2 & - & 2 \\ & & \\ - & & \\ - & 1 & 1 \\ - & 1 & 1 \\ - & 1 & 2 \\ - & 2 & 3\end{array}$

\section{Pinched}

parallel pinched ridges

vertical pinched ridges

$-$


Table 28. Decorative methods and elements represented in the utility ware and fine ware ceramics at the Childress site (41SA96), cont.

\begin{tabular}{llll}
\hline Ware & Rim & Body & N \\
\hline Punctated & & & 2 \\
fingernail punctated rows & 1 & 1 & 1 \\
diagonal linear tool punctated rows & 1 & - & 1 \\
diagonal tool punctated rows & 1 & - & 6 \\
tool punctated rows & 1 & 5 &
\end{tabular}

\section{Fine Ware}

\section{Engraved}

cross-hatched engraved zone and diagonal $\begin{array}{lll}- & 1\end{array}$

opposed engraved lines

diagonal engraved lines

diagonal opposed engraved lines

parallel engraved lines

straight engraved line

vertical panels with hatched corners or sets

$1 \quad 1 \quad 2$

$\begin{array}{lll}- & 1 & 1\end{array}$

$\begin{array}{lll}- & 3\end{array}$

of closely-spaced curvilinear engraved lines

Sherds from vessels with incised decorative elements comprise 29 percent of the decorated sherds from the Childress site (see Table 28). Incised rims have horizontal, horizontal-diagonal, or vertical incised elements. Other utility wares have punctated (10 percent), incised-punctated ( 8 percent), and pinched ( 3 percent) decorative elements (see Table 28); the pinched sherds are from Killough Pinched vessels. The punctated sherds have rows of either tool ( 80 percent) or fingernail ( 20 percent) punctations. The incised-punctated sherds have either circular or triangular incised zones filled primarily with tool punctations (see Table 28).

The one engraved rim sherd in the Childress site ceramic assemblage has diagonal engraved lines (see Table 28). Body sherds have simple geometric elements, as well as a body sherd with a cross-hatched engraved zone and diagonal opposed engraved lines (Figure 23b) and another body sherd with vertical panels that have hatched corners or sets of closely-spaced curvilinear engraved lines (Figure 23a).

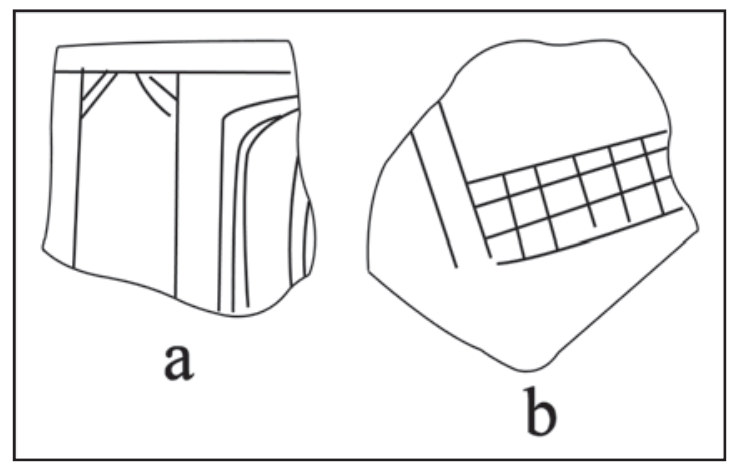

Figure 23. Selected decorative elements on engraved fine ware sherds from the Childress site (41SA96). 


\section{SA108}

About 52 percent of the ancestral Caddo ceramic vessel sherd assemblage from 41SA108 are from bone-tempered vessels (Table 29), and the remainder are from grog-tempered vessels. The highest proportion of bone-tempered sherds are in the utility wares (58.6 percent).

Table 29. Caddo ceramic wares at 41SA108.

\begin{tabular}{lccc}
\hline Ware & Grog-tempered & Bone-tempered & N \\
\hline Plain & 30 & 30 & 60 \\
Utility & 12 & 17 & 29 \\
Fine & 1 & - & 1 \\
\hline Totals & 43 & 47 & 90 \\
\hline
\end{tabular}

The plain to decorated sherd ratio in the 41SA108 assemblage is 2.00 . About 97 percent of the decorated sherds are from utility wares (Table 30). Brushed and brushed-incised sherds comprise 36.7 percent of the decorated sherds, and the brushed to plain sherd ratio is 0.18 ; the brushed to other wet paste sherds ratio is 0.58 .

Table 30. Decorative methods and elements represented in the utility ware and fine ware ceramics at 41SA108.

\begin{tabular}{llll}
\hline Ware & Rim & Body & $\mathrm{N}$ \\
\hline
\end{tabular}

\section{Utility Ware}

\section{Brushed}

horizontal brushed

parallel brushed

$\begin{array}{lll}1 & - & 1 \\ - & 9 & 9\end{array}$

Brushed-Incised

parallel brushed-incised marks and lines

-
-
-
-

Incised

horizontal incised lines

horizontal and diagonal incised lines

parallel incised lines

straight incised line

1

Incised-Punctated

triangular incised zones filled with circular punctates

vertical and diagonal incised lines above rows of circular punctates

\section{Punctated}

small circular punctated rows

fingernail punctated rows 
Table 30. Decorative methods and elements represented in the utility ware and fine ware ceramics at 41SA108, cont.

\begin{tabular}{llcc}
\hline Ware & Rim & Body & N \\
\hline $\begin{array}{l}\text { linear tool punctated row } \\
\text { tool punctated rows }\end{array}$ & - & 1 & 1 \\
Fine Ware & - & 2 & 2 \\
$\begin{array}{l}\text { Engraved } \\
\text { horizontal engraved lines }\end{array}$ & 1 & - & 1 \\
\hline Totals & 3 & 27 & 30 \\
\hline
\end{tabular}

Sherds with incised decorative elements comprise 30 percent of the decorated sherds at 41SA108. This includes a horizontal incised rim and a body sherd with horizontal and diagonal incised decorative elements (Figure 24a). Two sherds have incised-punctated decorative elements (6.7 percent of the decorated sherds), one with zones filled with circular punctations (Figure 24c), and another with vertical and diagonal incised lines on the rim above rows of small circular punctates on the vessel body (Figure 24b). Sherds with rows of either circular, fingernail, or tool punctates represent 23.3 percent of the 41SA108 decorated sherds (see Table 30).

The single engraved sherd in the 41SA108 ceramic vessel sherd assemblage is a rim with horizontal engraved lines (see Table 30).

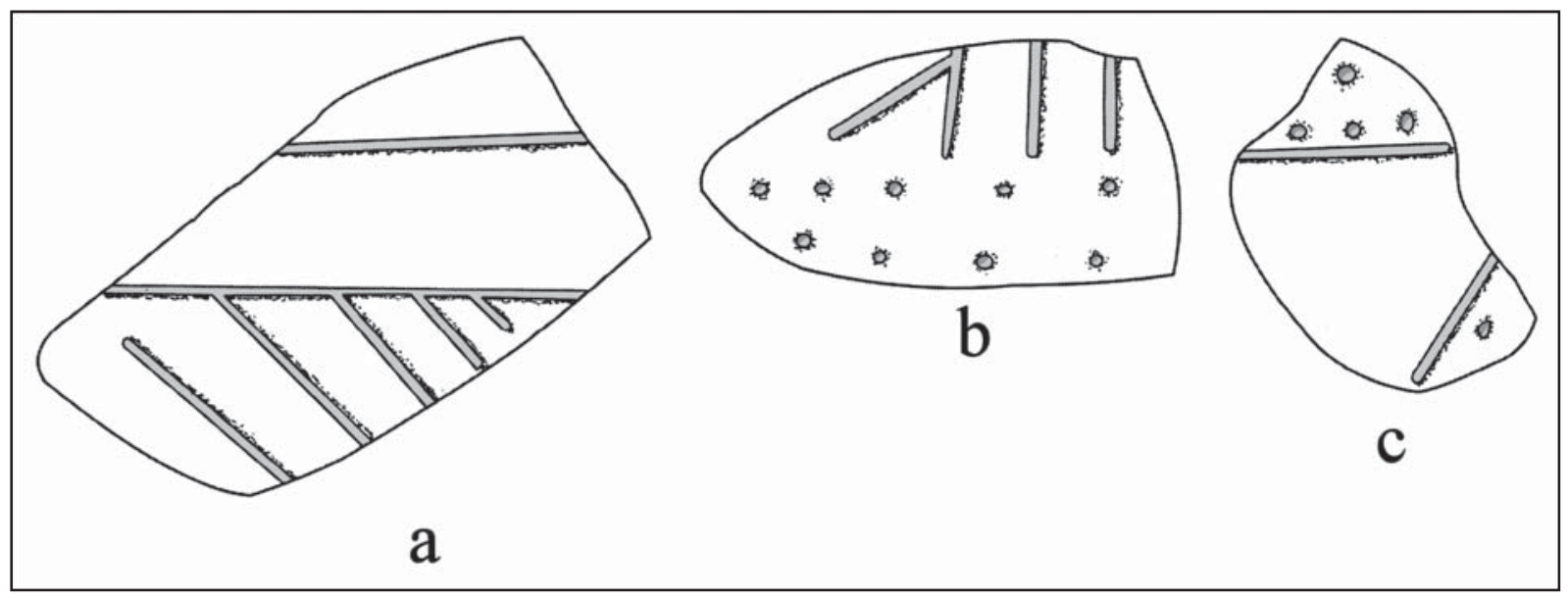

Figure 24. Selected decorative elements in the utility ware sherds from 41SA108. 


\section{Ceramic Pipe Sherds}

One plain grog-tempered elbow pipe bowl rim, with a flat lip, is in the collections from the Hamp Walldan site (41SA1). The bowl is $5.0 \mathrm{~mm}$ thick, and has a $23.1+\mathrm{mm}$ orifice diameter. A plain bonetempered collared elbow pipe bowl rim sherd with a flat lip was found at the Forest Johnson Lumber Co. site (41SA5). This pipe bowl is $7.4 \mathrm{~mm}$ thick and has a $29.5+\mathrm{mm}$ exterior orifice diameter.

Two ceramic pipe sherds are in the collections from the H. L. Gambles site (41SA9). The first is a bone-tempered plain elbow pipe bowl rim (3.2 $\mathrm{mm}$ in thickness), and the second is a grog-tempered long-stemmed Red River pipe stem sherd, with a stem thickness of $4.1 \mathrm{~mm}$. The basal stem/knob of a bone-tempered plain elbow pipe stem was in the collections from the J. McGilberry site (41SA85). The pipe walls are $5.6 \mathrm{~mm}$ thick. The D. C. Hines site collection (41SA95) has a single grog-tempered Red River pipe stem with a $9.5 \mathrm{~mm}$ exterior orifice diameter and a $2.3 \mathrm{~mm}$ stem hole; this is likely from a Graves Chapel variety of Red River pipe (see Hoffman 1967:9).

\section{Other Clay Artifacts}

Single pieces of burned clay are in the collections from the H. L. Gambles site (41SA9) and the E. D. Kinon Place III site (41SA15), along with two pieces of daub from a burned Caddo house structure from the H. C. Barton site (41SA32). At the E. D. Kinon Place IV site (41SA16), the collection has four pieces of burned clay and a clay coil (10.3 mm thick).

\section{Summary and Conclusions}

During the fall and winter of 1939 and early 1940, Gus E. Arnold identified and recorded many archaeological sites in San Augustine County, Texas, as part of the WPA-sponsored archaeological survey of East Texas carried out by The University of Texas at Austin. In the course of his archaeological survey efforts, Arnold collected a wide range of stone and/or ceramic artifacts from sites dating from Paleoindian, Archaic, Woodland (Mossy Grove culture), and ancestral Caddo occupations; in particular, he amassed a substantial sample of Caddo ceramic vessel sherds from East Texas sites, and in this article I have discussed in particular the character and diversity of the ancestral Caddo ceramics (including a few ceramic pipe sherds) in large sherd assemblages from 14 different sites in the Angelina River, Attoyac Bayou, Ayish Bayou, Palo Gaucho Bayou, and Patroon Bayou drainage basins (see Figure 1) in San Augustine County.

The first finding from the analysis of the Caddo ceramics is that these ancestral Caddo sites in these drainage basins likely all date after ca. A.D. 1200 because there are decorated brushed sherds in each one (Table 31). Sherds from brushed utility ware vessels, particularly jars, are a distinctive characteristic of only Middle (ca. A.D. 1200-1400), Late (ca. A.D. 1400-1680), and Historic Caddo sites (ca. post-A.D. 1680) in much of East Texas (Figure 25), and thus their appearance in a Caddo ceramic assemblage bespeaks a post-ca. A.D. 1200 occupation. From other analyses of brushed ceramics on Caddo sites in East Texas (see Perttula 2013), it also appears to be the case that the relative proportions of brushed utility wares increase through time from Middle to Historic Caddo periods in those areas where brushed vessels were made and used, such that sherds with brushing marks may comprise as much as 90 percent of all the decorated sherds in some post-A.D. 1400 East Texas ceramic assemblages.

The second finding is that the use of burned animal bone for the temper of ceramic vessels is another distinctive characteristic of East Texas Caddo ceramic sherd assemblages, and most ceramic assemblages in the region have some bone-tempered sherds. However, sherd assemblages with high proportions ( $>40$ percent of the sherd assemblage) of bone temper are concentrated in only a few locales across East Texas, most notably in the Toledo Bend Reservoir area along the middle Sabine River and in sites in the Angelina River basin (Figure 26), including almost all the ceramic assemblages discussed in this article. 
Table 31. The highest proportion of decorative elements and bone-tempered sherds by sites in different drainage basins in San Augustine County, Texas.

\begin{tabular}{|c|c|c|c|c|c|}
\hline Decorative method & Angelina & Attoyac & Patroon & $\begin{array}{l}\text { Palo } \\
\text { Gaucho }\end{array}$ & Ayish \\
\hline Appliqued & & + & & & + \\
\hline Appliqued-Incised & & & & & + \\
\hline Brushed & + & + & + & & \\
\hline Brushed-Appliqued & & + & & & \\
\hline Brushed-Incised & & & + & + & \\
\hline Brushed-Punctated & & + & & & \\
\hline $\begin{array}{l}\text { Brushed-Punctated- } \\
\text { Appliqued }\end{array}$ & + & & & & \\
\hline Incised & & & & & + \\
\hline Incised-Pinched & + & & & & \\
\hline Incised-Punctated & + & & & & + \\
\hline Pinched & & + & & & + \\
\hline Cane Punctated & & & & & + \\
\hline Circular Punctated & & & & + & + \\
\hline Fingernail Punctated & & & & & + \\
\hline Tool Punctated & & + & & & \\
\hline Ridged & & & + & & \\
\hline Engraved & & + & & & + \\
\hline Engraved-Slipped & & + & & & \\
\hline Slipped & & & + & & \\
\hline Trailed & & & & & + \\
\hline Percent Bone Temper & & & + & + & \\
\hline
\end{tabular}

Pre-A.D. 1400/1450 Caddo sites with a high proportion of bone temper are found only in a few areas in the middle Sabine River basin. Late Caddo (ca. A.D. 1400-1680) sites and assemblages with high proportions of bone temper are found in a number of sites in the mid-Sabine and Angelina River basins (see Figure 26). In fact, these sites are part of a previously identified Late Caddo period bone-tempered and brushed ceramic tradition (Perttula 2011:Figure 6-71). Historic Caddo sites (dating from ca. A.D. 1700-1830) with high percentages of bone temper use are known only in the upper and middle Sabine River basins, and in the lower parts of the Angelina River basin (see Figure 26).

Third, although several of the sites under discussion in this article occur on Ayish Bayou, none of the sites considered here appear to be associated with the Ais groups living in the area around presentday San Augustine, Texas in the $18^{\text {th }}$ and early $19^{\text {th }}$ centuries. The Mission Dolores de los Ais (41SA25) ceramic assemblage (see Corbin et al. 1980, 1990) differs the most from surrounding ancestral Caddo sites by: (1) the very high proportions of bone temper and shell temper use in vessel manufacture; (2) the virtual absence of brushed utility wares; (3) the presence of Emory Punctated-Incised and Natchitoches Engraved vessel sherds; and (4) the overall high proportions of engraved fine wares---56.3 percent - at the site. This suggests that the Mission Dolores de los Ais ceramic assemblage stands apart in several distinctive ways from Late to Historic Caddo ceramic assemblages associated with Hasinai Caddo groups living in adjoining drainage basins in this part of East Texas. If the Mission Dolores de los Ais ceramics are a representative sample of the character of an $18^{\text {th }}$ century Ayish ceramic assemblage, then it seems apparent 


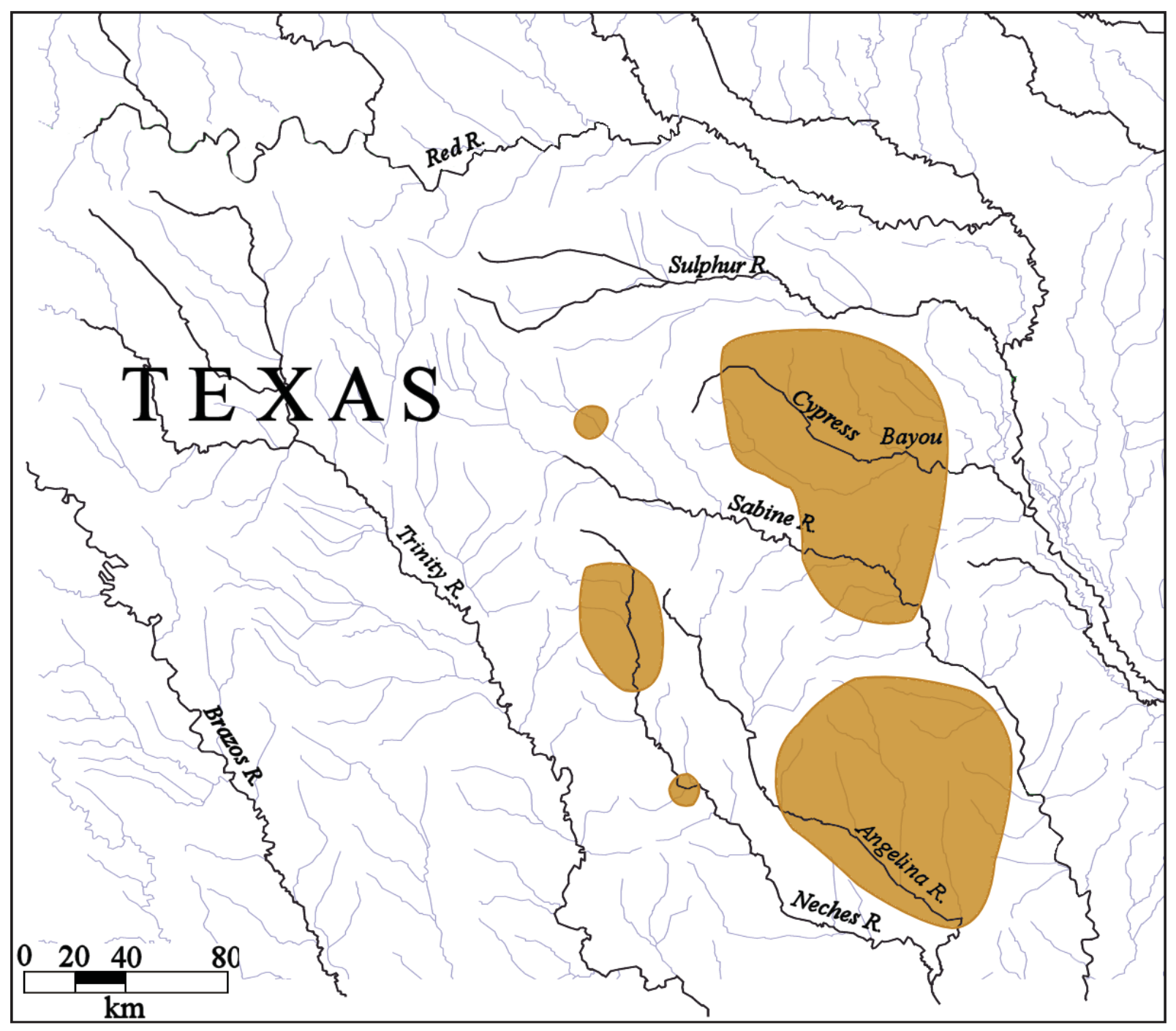

Figure 25. Caddo site clusters with high proportions ( $>60$ percent of decorated ceramic assemblages) of brushed sherds in East Texas.

that sites in the Angelina, Attoyac, Palo Gaucho Bayou, Patroon Bayou, and even sites in the Ayish Bayou basins in Nacogdoches, San Augustine, and Sabine counties that date after ca. A.D. 1200 to as late as ca. A.D. 1680-1720 are not part of an Ayish ceramic tradition but are part of an ancestral Hasinai ceramic tradition.

Additionally, while the San Augustine County Caddo sites considered herein share the manufacture and use of brushed and bone-tempered ceramic vessels, there is a considerable diversity in their use, and in the occurrence of sherds from other decorated utility ware and fine ware vessels. Table 31 indicates that site ceramic assemblages in the Attoyac and Ayish bayous are most similar in the range and proportion of utility wares - in particular sites with high proportions of sherds with brushed decorative elements versus sites with high proportions of incised, incised-punctated, punctated, and engraved decorative elements followed by sites in the Patroon and Palo Gaucho bayous (these sites also have the highest proportion of bone-tempered sherds), sites in the Attoyac and Patroon bayous, and that the sites in the Angelina River basin are the most divergent of the 14 San Augustine County sites. Spatially, the Angelina River sites are the western and southernmost in the county (see Figure 1), while the other sites (either on tributaries of the Angelina or Sabine rivers) are located to the north and northeast of the Angelina River, mainly in the upper parts of tributary streams. These similarities and dissimilarities in the range and proportion of 


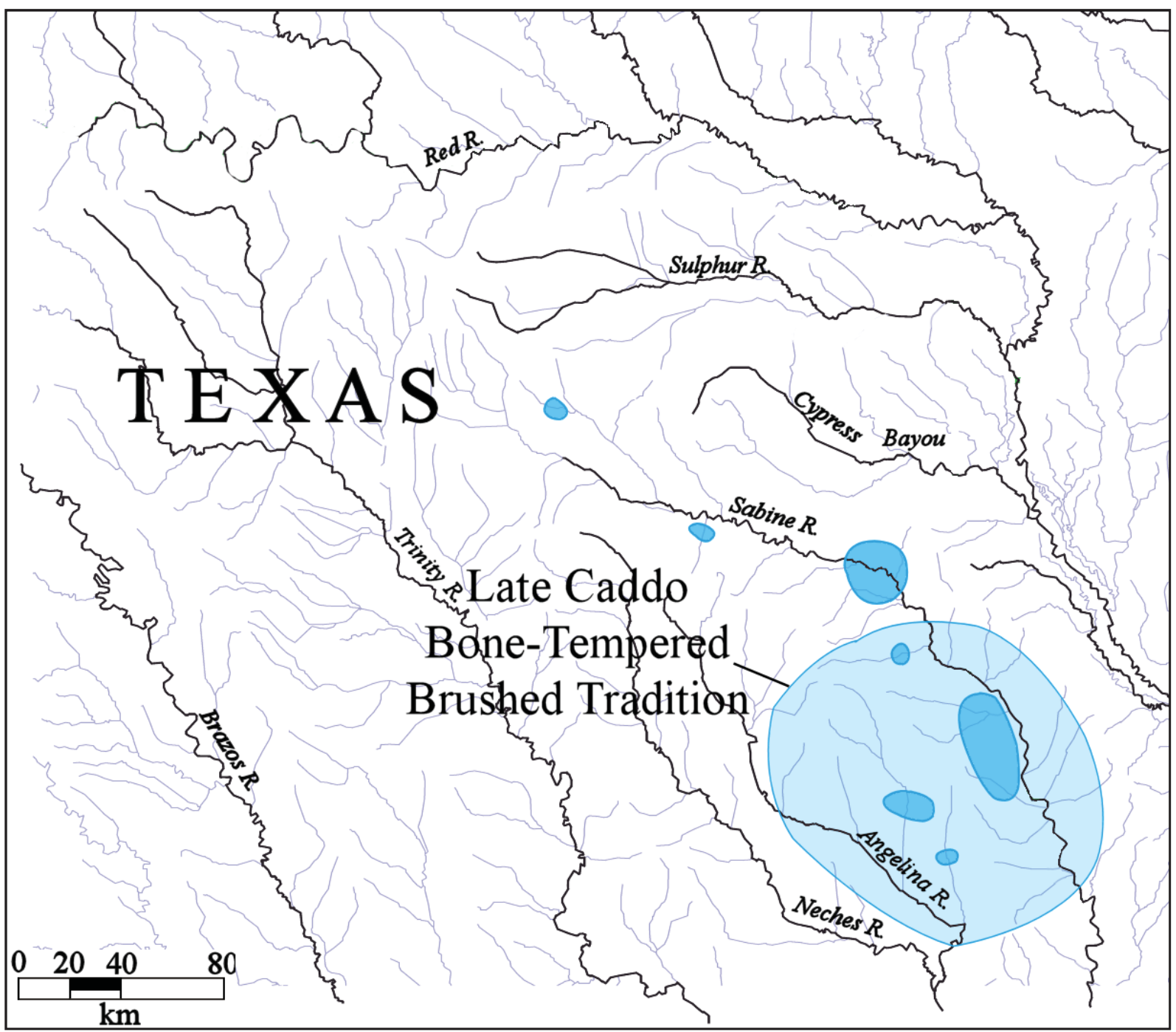

Figure 26. Clusters of Caddo sites with high proportions (>than 40 percent) of bone-tempered sherds in East Texas ceramic assemblages.

different utility ware and fine ware sherds likely relates to differences in the extent of social interaction and networking between ancestral Caddo groups, after ca. A.D. 1200 in this part of East Texas.

There are also clear differences between these sites in different stream basins in East Texas in the co-association of bone-tempered sherds and brushed vessel sherds (Figure 27 and Table 32). They can be readily sorted into groups that may share social and technological traditions: A, low to moderate brushed and low to moderate bone-tempered (Ayish Bayou sites primarily, but also certain sites in the Angelina, Attoyac, and Palo Gaucho basins); B, moderate bone-tempered and high brushed sherds (Angelina River sites); C, moderate to high bone-tempered and moderate brushed sherds (mainly Palo Gaucho Bayou sites, with single sites in the Ayish and Attoyac Bayou basins); and D, high bone-tempered and high brushed (primarily Attoyac Bayou sites, along with two Patroon Bayou sites). In the case of just these two variables, Table 32 indicates that the Angelina and Ayish Bayou sites with the highest proportion of brushed sherds in an assemblage in these drainages are the most divergent from each other, while the assemblages in the Attoyac, Patroon, and Palo Gaucho bayous are the most similar in percentage of brushed sherds among all the decorated sherds in an assemblage, in the proportions of bone-tempered sherds, and in the plain to decorated sherd ratios. 


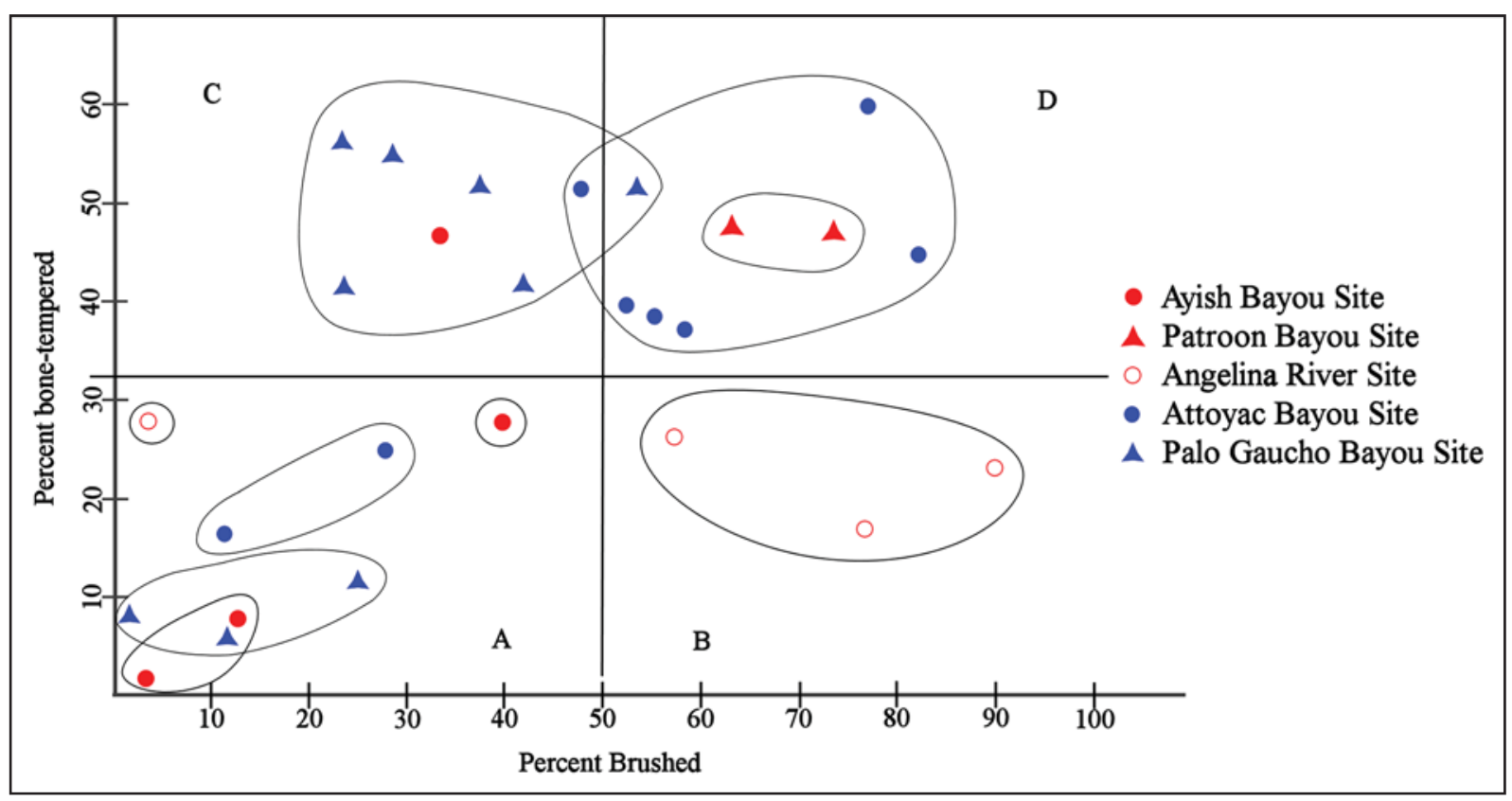

Figure 27. Co-association of percent bone-tempered and percent brushed in the sherds from sites in the Ayish Bayou, Patroon Bayou, Angelina River, Attoyac Bayou, and Palo Gaucho Bayou in San Augustine County, Texas.

Table 32. Assemblage groupings by drainage basin with the highest percentages of brushed pottery in any site in the basin.

\begin{tabular}{lccc}
\hline Drainage & \% Brushed & P/DR & \% bone temper \\
\hline Angelina River & 90.0 & 0.26 & 24.8 \\
& & & \\
Attoyac Bayou & 81.7 & 0.56 & 45.0 \\
Palo Gaucho Bayou & 53.2 & 0.79 & 52.1 \\
Patroon Bayou & 48.6 & 0.45 & 64.0 \\
Ayish Bayou & 50.0 & 1.57 & 28.0 \\
\hline
\end{tabular}

$\mathrm{P} / \mathrm{DR}=$ plain to decorated sherd ratio

As mentioned above, these 14 San Augustine County ancestral Caddo sites were primarily occupied after ca. A.D. 1200, and in most cases, the principal occupations took place sometime after ca. A.D. 1400. The best indication in the ceramic artifacts and in the arrow points of some use of the sites prior to A.D. 1200 are a single Coles Creek Incised, var. Coles Creek sherd from the Hamp Walldan site (41SA1), Weches Fingernail Impressed, var. Weches sherds at the Hamp Walldan and John McGilberry (41SA85) sites, and Alba or Catahoula arrow points at five of the sites. Long-stemmed Red River style pipe sherds at the H. L. Gambles (41SA9) and D. C. Hines (41SA95) sites are also evidence of pre-A.D. 1200 use by Caddo peoples.

None of these ancestral Caddo sites have any radiocarbon dates to help with determining their chronological age. Instead, in proposing the likely age of the principal Caddo components in the 
different drainage basins, as well as other previously studied ceramic assemblages in this region, I rely on certain utility ware ceramic metrics, the proportion of brushed sherds in assemblages in the different stream basins, and the identification of certain ceramic types in the decorated sherd assemblages (see above), including Belcher Ridged, Emory Punctated-Incised, Glassell Engraved, Keno Trailed, Killough Pinched, Maydelle Incised, Patton Engraved, Pease Brushed-Incised, Pineland Punctated-Incised, Poynor Engraved, Spradley Brushed-Incised, and Taylor Engraved. Elbow pipes are also characteristic of Late and Historic Caddo period Caddo use and settlement, and elbow pipes are present at the Hamp Walldan (41SA1), Frost Johnson Lumber Co. (41SA5), H. L. Gambles (41SA9), and the John McGilberry (41SA85) sites. Of the 28 sites/assemblages listed in Table 33, 21 percent are considered to be of Middle Caddo period age (ca. A.D. 1200-1400), another 71 percent are considered to be of Late Caddo period age (ca. A.D. 1400-1680), and 7.1 percent, with numerous Patton Engraved sherds, may be of Historic Caddo period age (ca. A.D. 1680-1720); the two Historic Caddo sites are in the Angelina and Ayish Bayou stream basins.

Table 33. Ceramic comparisons of sites in adjoining drainage basins in San Augustine, Sabine, and Angelina counties in East Texas, arranged from oldest to youngest (this article, Middlebrook 2010, and Perttula 2015a, 2015b, 2016, 2017a, 2017b).

\begin{tabular}{|c|c|c|c|c|c|}
\hline Drainage basin & $\begin{array}{l}\% \text { bone } \\
\text { temper }\end{array}$ & $\mathrm{P} / \mathrm{DR}$ & $\mathrm{B} / \mathrm{Pl}$ & B/OTP & $\begin{array}{l}\% \text { brushed } \\
\text { sherds among all } \\
\text { decorated sherds }\end{array}$ \\
\hline
\end{tabular}

Angelina River

Late Caddo period

41SB36

29.0

1.59

0.05

0.11

4.9

41SA85

25.9

1.16

0.51

1.87

55.3

$41 \mathrm{AG} 9$

16.4

0.40

1.91

2.61

75.5

Historic Caddo period

41AG10*

24.8

0.26

3.41

12.1

90.0

Attoyac Bayou

Middle Caddo period 41SA9

17.0

2.72

0.04

0.14

10.9

41SA13

25.0

1.43

0.20

0.54

28.3

Late Caddo period

41SA135**

46.0

1.13

1.79

0.40

0.27

1.00

1.12

40.3

41SA1*

38.7

1.23

0.45

1.46

41SA24*

40.0

0.72

0.74

1.30

41SA16

37.8

0.80

0.74

1.59

52.8

41SA7

60.0

0.67

1.15

4.54

76.1

41SA15

45.0

0.56

$1.46 \quad 5.10$

81.7 
Table 33. Ceramic comparisons of sites in adjoining drainage basins in San Augustine, Sabine, and Angelina counties in East Texas, arranged from oldest to youngest (this article, Middlebrook 2010, and Perttula 2015a, 2015b, 2016, 2017a, 2017b), cont.

\begin{tabular}{|c|c|c|c|c|c|}
\hline Drainage basin & $\begin{array}{l}\% \text { bone } \\
\text { temper }\end{array}$ & $\mathrm{P} / \mathrm{DR}$ & $\mathrm{B} / \mathrm{Pl}$ & B/OTP & $\begin{array}{l}\% \text { brushed } \\
\text { sherds among all } \\
\text { decorated sherds }\end{array}$ \\
\hline
\end{tabular}

Ayish Bayou

Middle Caddo period

41SA77 2.6

$\begin{array}{lllll}2.6 & 2.69 & 0.02 & 0.05 & 4.3 \\ 7.4 & 1.15 & 0.12 & 0.17\end{array}$

41SA95

7.4

1.15

0.12

0.17

13.4

Late Caddo period

41SA96

28.0

1.57

0.25

0.80

40.0

Historic Caddo period

41SA $80 *$

46.5

1.37

0.24

0.68

34.6

Palo Gaucho Bayou

Middle Caddo period

41SB28

9.0

2.00

$-$

$-$

0.7

41SA52

5.9

2.96

0.04

0.13

10.7

Late Caddo period

41SB34

11.0

$-$

0.34

25.1

41SB23

41.0

1.44

0.16

0.3

23.5

41SA48

55.5

1.46

0.16

0.5

23.7

41SA108

52.2

2.00

0.18

0.58

36.7

41SA26

55.0

1.42

0.21

0.70

29.2

41SB29

42.0

-

-

0.74

41.0

41SA50

52.1

0.79

0.68

1.16

52.2

\section{Patroon Bayou}

Late Caddo period

41SA32*

46.0

1.05

0.59

3.16

74.5

41SA11

48.6

0.45

1.41

2.13

64.0

$\mathrm{P} / \mathrm{DR}=$ plain/decorated sherd ratio; $\mathrm{B} / \mathrm{Pl}=$ brushed to plain sherd ratio; $\mathrm{B} / \mathrm{OTP}=$ brushed to other wet paste sherds ratio *Patton Engraved sherds are present

**from Middlebrook (2010)

The postulated Middle Caddo period ceramic assemblages have low proportions of bone-tempered ceramics (17-25 percent in Attoyac Bayou sites, 2.6-7.4 percent in Ayish Bayou sites, and 5.9-9.0 percent in Palo Gaucho Bayou sites), and the proportions of brushed utility wares range from only 0.7-28 percent. The highest proportion of brushed utility wares occur in the Attoyac Bayou sites. 
There are several distinctive groupings of Late Caddo period sites based on the ceramic metrics data in the utility wares (see Table 33). In the case of the Late Caddo period sites in the Attoyac and Palo Gaucho bayou basins, there appear to be temporal trends within the period in the proportion of bonetempered vessel sherds and proportion of brushed sherds among all the decorated sherds: in the Attoyac Bayou sites, the proportion of bone-tempered sherds may increase from 38.7 to 60.0 percent, while the proportion increases from 11.0 percent to 55.5 percent in Palo Gaucho Bayou sites. The proportion of brushed sherds in Late Caddo sites in these two basins may increase through time from 40.3 percent to 81.7 percent in the Attoyac and 25.1 percent to 52.2 percent in Palo Gaucho sites. The Angelina River basin Late Caddo sites are distinctive from the others in having moderate proportions of bone-tempered sherds (16.4-29.0 percent) but considerable numbers of brushed sherds (45.3-77.5 percent) in two sites, but a low proportion of brushed sherds from 41SB36 (see Perttula 2017a). The Ayish Bayou and Patroon Bayou sites with Late Caddo period ceramic assemblages appear to be contemporaneous with the earlier grouping (ca. A.D. 1400-1480) of Late Caddo sites in the Attoyac Bayou, while the Patroon Bayou Late Caddo period sites may have been occupied later in the period, and contemporaneous with the latest (ca. A.D. 1560-1680) Late Caddo sites in the Attoyac Bayou basin.

The two Historic Caddo sites differ considerably from each other in both the proportion of bonetempered sherds and the proportion of brushed utility wares in their ceramic sherd assemblages. The highest proportions of bone-tempered sherds are in the Ayish Bayou site (41SA80), while the highest proportion of brushed utility ware sherds is in the Angelina River site (41AG10).

\section{Acknowledgments}

Thanks to Lauren Bussiere at TARL for finding all these WPA collections and making them available for study. Lance Trask prepared the figures for this article.

\section{References Cited}

Aten, L. E.

1983 Indians of the Upper Texas Coast. Academic Press, New York.

Brown, I. W.

1998 Decorated Pottery of the Lower Mississippi Valley: A Sorting Manual. Mississippi Archaeological Association and Mississippi Department of Archives and History, Jackson.

Corbin, J. E., T. C. Alex, and A. Kalina

1980 Mission Dolores de los Ais. Papers in Anthropology No. 2. Stephen F. Austin State University, Nacogdoches.

Corbin, J. E., H. A. Brown, M. G. Canavan, and S. Toups

1990 Mission Dolores de los Ais (41SA25): San Augustine County, Texas, Archeological Investigations. Stephen F. Austin State University, Nacogdoches.

Ellis, L. W.

2013 Woodland Ceramics in East Texas and a Case Study of Mill Creek Culture Ceramics. Bulletin of the Texas Archeological Society 84:137-180.

Girard, J. S.

2014 The James Pace Site (16DS268) and Early Caddo Developments Along the Upper Sabine River. Bulletin of the Texas Archeological Society 85:61-81.

Hoffman, M. P.

1967 Ceramic Pipe Style Chronology along the Red River Drainage in Southwestern Arkansas. The Arkansas Archeologist 8(1):4-14. 
Jelks, E. B.

1965 The Archeology of McGee Bend Reservoir, Texas. Ph.D. dissertation, Department of Anthropology, The University of Texas at Austin.

Middlebrook, $\mathrm{T}$.

2010 The Jack Walton Site (41SA135), San Augustine County, Texas. Journal of Northeast Texas Archaeology 33:1-23.

Perttula, T. K.

2011 The Ceramic Artifacts from the Lang Pasture Site (41AN38) and the Place of the Site within an Upper Neches River Basin Caddo Ceramic Tradition. In Archeological Investigations at the Lang Pasture Site (41AN38) in the Upper Neches River Basin of East Texas, assembled and edited by T. K. Perttula, D. B. Kelley, and R. A. Ricklis, pp. 145-320. Archeological Studies Program Report No. 129, Texas Department of Transportation, Environmental Affairs Division, Austin.

2015a Two Caddo Sites in the Attoyac Bayou Basin in the East Texas Pineywoods, San Augustine County, Texas. Journal of Northeast Texas Archaeology 54:41-53.

2015b Caddo Sites on Patroon, Palo Gaucho, and Housen Bayous in Sabine County in the Sabine River Basin of East Texas. Journal of Northeast Texas Archaeology 54:63-91.

2016 Caddo Ceramic Assemblages from Sites in the Ayish and Palo Gaucho Bayou Basins, San Augustine County, Texas. Journal of Northeast Texas Archaeology 70;13-31.

2017a The Beckham (41SB35) and Print Bell (41SB36) Woodland Period and Caddo Ceramic Assemblages Collected by G. E. Arnold in 1939, Sabine County, Texas. Journal of Northeast Texas Archaeology 71:135-146.

2017b 41AG9 and 41AG10: Ancestral Caddo Sites on Percella Creek in the Angelina River Basin in East Texas. Journal of Northeast Texas Archaeology 72, this volume.

Perttula, T. K. and R. Z. Selden Jr.

2014 Ancestral Caddo Ceramics in East Texas. Journal of Northeast Texas Archaeology 48:9-58.

Stokes, J. and J. Woodring

1981 Native-Made Artifacts of Clay. In Archeological Investigations at the George C. Davis Site, Cherokee County, Texas: Summers of 1979 and 1980, edited by D. A. Story, pp. 135-238. Occasional Paper No. 1. Texas Archeological Research Laboratory, The University of Texas at Austin.

Story, D. A.

1990 Cultural History of the Native Americans. In The Archeology and Bioarcheology of the Gulf Coastal Plain, by D. A. Story, J. A Guy, B. A. Burnett, M. D. Freeman, J. C. Rose, D. G. Steele, B. W. Olive, and K. J. Reinhard, pp. 163-366. Research Series No. 38. 2 Vols. Arkansas Archeological Survey, Fayetteville.

Suhm, D. A. and E. B. Jelks (editors)

1962 Handbook of Texas Archeology: Type Descriptions. Special Publication No. 1, Texas Archeological Society, and Bulletin No. 4, Texas Memorial Museum, Austin. Reprinted in 2009, Gustav's Library, Davenport, Iowa. 